\title{
Three distinct Holocene intervals of stalagmite deposition and nondeposition revealed in NW Madagascar, and their paleoclimate implications
}

\author{
Ny Riavo Gilbertinie Voarintsoa ${ }^{1, a}$, Loren Bruce Railsback ${ }^{1}$, George Albert Brook ${ }^{2}$, Lixin Wang ${ }^{2}$, Gayatri Kathayat ${ }^{3}$, \\ Hai Cheng ${ }^{3,4}$, Xianglei $\mathrm{Li}^{3}$, Richard Lawrence Edwards ${ }^{4}$, Amos Fety Michel Rakotondrazafy ${ }^{5}$, and Marie \\ Olga Madison Razanatseheno ${ }^{5}$ \\ ${ }^{1}$ Department of Geology, University of Georgia, Athens, GA 30602-2501, USA \\ ${ }^{2}$ Department of Geography, University of Georgia, Athens, Georgia, 30602-2502, USA \\ ${ }^{3}$ Institute of Global Environmental Change, Xi' an Jiaotong University, Xi' an, Shaanxi 710049, P.R. China \\ ${ }^{4}$ Department of Earth Sciences, University of Minnesota, Minneapolis, Minnesota 55455, USA \\ ${ }^{5}$ Mention Sciences de la Terre et de l'Environnement, Domaine Sciences et Technologie, \\ University d'Antananarivo, Madagascar \\ ${ }^{a}$ current address: Institute of Earth Sciences, The Hebrew University in Jerusalem, A. Safra Campus, 91904, Jerusalem, Israel \\ Correspondence to: Ny Riavo Gilbertinie Voarintsoa (nv1@uga.edu, nyriavony@gmail.com)
}

Received: 26 December 2016 - Discussion started: 16 January 2017

Revised: 12 October 2017 - Accepted: 28 October 2017 - Published: 4 December 2017

\begin{abstract}
Petrographic features, mineralogy, and stable isotopes from two stalagmites, ANJB-2 and MAJ-5, respectively from Anjohibe and Anjokipoty caves, allow distinction of three intervals of the Holocene in NW Madagascar. The Malagasy early Holocene (between ca. 9.8 and $7.8 \mathrm{ka}$ ) and late Holocene (after ca. 1.6 ka) intervals (MEHI and MLHI, respectively) record evidence of stalagmite deposition. The Malagasy middle Holocene interval (MMHI, between ca. 7.8 and $1.6 \mathrm{ka}$ ) is marked by a depositional hiatus of ca. 6500 years.

Deposition of these stalagmites indicates that the two caves were sufficiently supplied with water to allow stalagmite formation. This suggests that the MEHI and MLHI intervals may have been comparatively wet in NW Madagascar. In contrast, the long-term depositional hiatus during the MMHI implies it was relatively drier than the MEHI and the MLHI.

The alternating wet-dry-wet conditions during the Holocene may have been linked to the long-term migrations of the Intertropical Convergence Zone (ITCZ). When the ITCZ's mean position is farther south, NW Madagascar experiences wetter conditions, such as during the MEHI and MLHI, and when it moves north, NW Madagascar climate becomes drier, such as during the MMHI. A similar wet-
\end{abstract}

dry-wet succession during the Holocene has been reported in neighboring locations, such as southeastern Africa. Beyond these three subdivisions, the records also suggest wet conditions around the cold $8.2 \mathrm{ka}$ event, suggesting a causal relationship. However, additional Southern Hemisphere highresolution data will be needed to confirm this.

\section{Introduction}

Although much is known about Holocene climate change worldwide (Mayewski et al., 2004; Wanner and Ritz, 2011; Wanner et al., 2011, 2015), high-resolution climate data for the Holocene period is still regionally limited in the Southern Hemisphere (SH) (e.g., Wanner et al., 2008, 2015; Marcott et al., 2013), including Madagascar. This uneven distribution of data hinders our understanding of the spatiotemporal characteristics of Holocene climate change and the forcings involved. For example, some forcings would have influenced the behavior of the Intertropical Convergence Zone (ITCZ) as well as monsoonal responses in low- to midlatitude regions (e.g., Wanner et al., 2015; Talento and Barreiro, 2016). In fact, Madagascar is ideally located to provide data on SH Holocene climate changes because of its location 

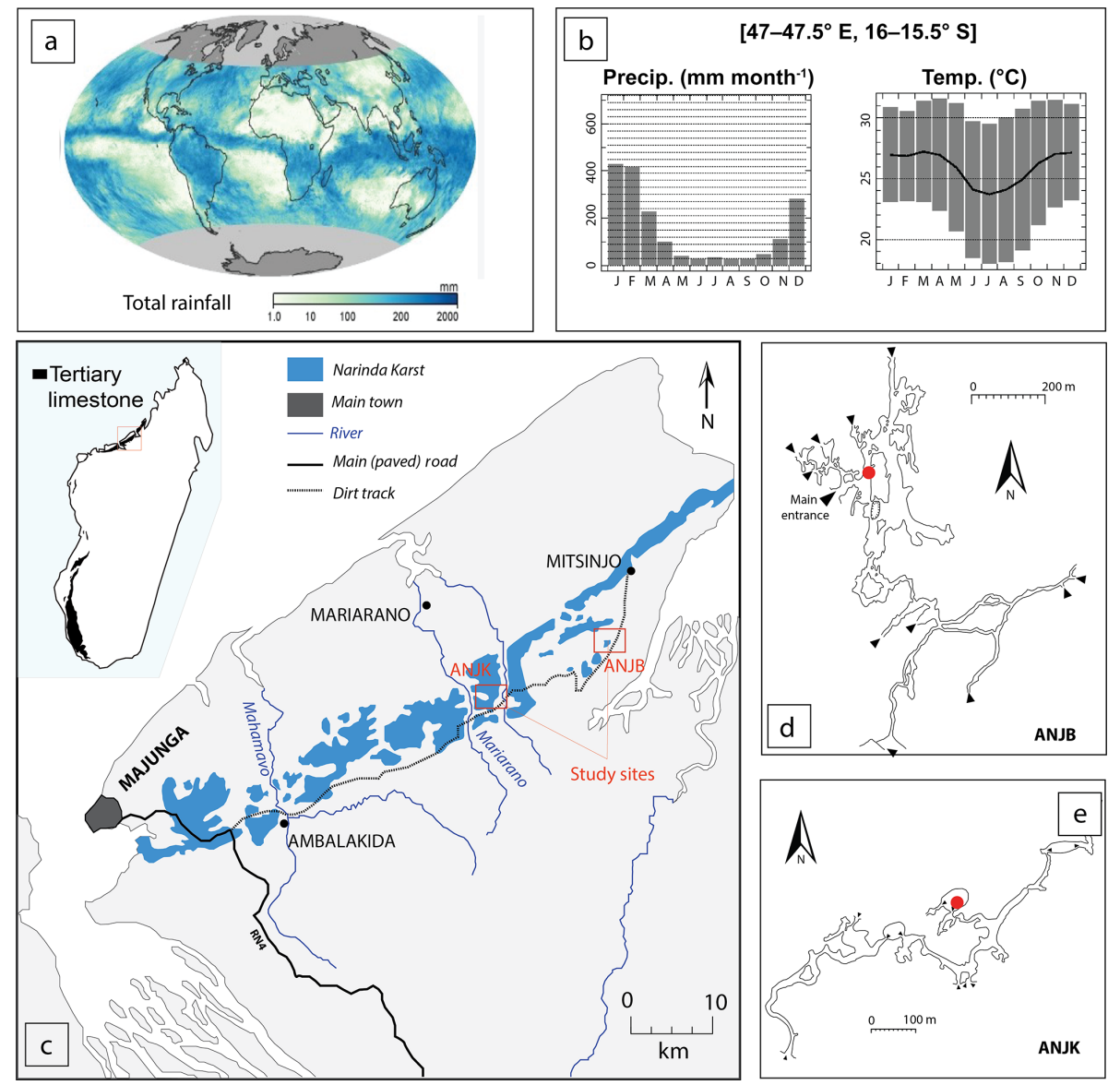

Figure 1. Climatological and geographic setting of Madagascar and the study area. (a) Global rainfall maps recorded by NASA's Tropical Rainfall Measuring Mission (TRMM) satellite showing the total monthly rainfall in millimeters and the overall position of the ITCZ during November, 2006. Darker shades of blue indicate regions of higher rainfall (source: NASA Earth Observatory, 2016). (b) Bar plots of monthly precipitation and monthly average of daily maximum, minimum, and mean temperature in NW Madagascar, based on 1971-2000 climate data. Source: http://iridl.ldeo.columbia.edu/ (access: 31 August 2016). (c) Simplified map showing the southwestern part of the Narinda karst and the location of the study areas. Inset figure is a map of Madagascar showing the extent of the Tertiary limestone outcrop that makes up the Narinda karst. (d-e) Maps of Anjohibe (ANJB) and Anjokipoty (ANJK) caves (St-Ours, 1959; Middleton and Middleton, 2002), with approximate location for sample collection (red dots). See Figs. S1-S3 in the Supplement for additional information about the study locations.

in the southwestern Indian Ocean and because it is seasonally visited by the ITCZ (Fig. 1a). Furthermore, a karst belt with caves extends from the north to the south of the island (Fig. 1c), crossing latitudinal climate belts, and this could potentially be a source of stalagmite data. Thus, Madagascar is a natural laboratory to study ITCZ dynamics over time. New records from Madagascar could fill gaps in paleoclimate datasets for the SH that might help refine paleoclimate simulations, and thus provide a better understanding of global circulation and land-atmosphere-ocean interactions during the Holocene.

In this paper, we present records of stable isotopes, petrography, mineralogy, variability in layer-specific width (LSW) from stalagmites from Anjohibe and Anjokipoty caves. Stalagmites are used because of their potential to store significant climatic information (e.g., Fairchild and Baker, 2012, p. 9-10), and in Anjohibe Cave recent studies have shown the replicability of paleoclimate records from stalagmites (e.g., Burns et al., 2016).

Two stalagmites were investigated, and these allowed us to characterize Holocene climate change in NW Madagascar. First, we developed a record of climate change using the stalagmite proxy data. With a better understanding of Madagascar's paleoclimate, we then investigated possible drivers of tropical climate change to isolate the major factors controlling the hydrological cycle in NW Madagascar and surrounding regions during the Holocene. 


\section{Setting}

\subsection{Stalagmites and their setting}

Stalagmites are secondary cave deposits that are $\mathrm{CaCO}_{3}$ precipitates from cave drip water. Calcium carbonate precipitation occurs mainly by $\mathrm{CO}_{2}$ degassing, which increases the $\mathrm{pH}$ of the drip water and thus increases the concentration of $\mathrm{CO}_{3}^{2-}$. In some cases, evaporation may also contribute to increased $\mathrm{Ca}^{2+}$ and/or $\mathrm{CO}_{3}^{2-}$ concentrations in drip water. $\mathrm{CO}_{2}$ degassing occurs when high- $P \mathrm{CO}_{2}$ water from the epikarst encounters low- $\mathrm{PCO}_{2}$ cave air. Evaporation occurs when humidity inside the cave is relatively low. The fundamental equation for stalagmite deposition-nondeposition is

$\mathrm{Ca}_{(\mathrm{aq})}^{2+}+2 \mathrm{HCO}_{3(\mathrm{aq})}^{-} \rightleftharpoons \mathrm{CaCO}_{3(\mathrm{~s})}+\mathrm{CO}_{2(\mathrm{~g})}+\mathrm{H}_{2} \mathrm{O}_{(\mathrm{l})}$.

Growth and nongrowth of stalagmites depends on conditions that affect Eq. (1). An increase in $\mathrm{Ca}^{2+}$ drives the equation to the right (towards precipitation) and an increase in $\mathrm{CO}_{2}$ of the cave air and/or $\mathrm{H}_{2} \mathrm{O}$ drives it to the left (towards dissolution). All components of the equation are influenced by the supply of water to the cave, which is generally climate-dependent. More water enters the cave during warm-rainy seasons than during cold-dry seasons. Stalagmites will form when cave drip water is saturated with respect to calcite and/or aragonite. If the water passes through the bedrock too quickly to dissolve significant carbonate rock, and/or enters the cave and reaches the stalagmite too quickly to degas significant $\mathrm{CO}_{2}$, it will not be saturated with respect to $\mathrm{CaCO}_{3}$, inhibiting stalagmite formation. Stalagmite growth will slow as drip water declines and will stop entirely if flow ceases. Vegetation provides $\mathrm{CO}_{2}$ to the soil via root respiration; thus, the vegetation cover above the cave and the type of vegetation can promote or limit stalagmite growth. Overall, the karst hydrological system plays a crucial role in the deposition and nondeposition of stalagmites, and this is closely linked to changes in local and regional environment and climate.

\subsection{Regional environmental setting}

Stalagmites ANJB-2 and MAJ-5 were collected from Anjohibe and Anjokipoty caves, respectively, in the Mahajanga region of NW Madagascar (Fig. 1). Sediments and fossils from these caves have already provided many insights about the paleoenvironmental and archaeological history of NW Madagascar (e.g., Burney et al., 1997, 2004; Brook et al., 1999; Gommery et al., 2011; Jungers et al., 2008; Vasey et al., 2013; Burns et al., 2016; Voarintsoa et al., 2017b).

Anjohibe $\left(\mathrm{S} 15^{\circ} 32^{\prime} 33.3^{\prime \prime}, \mathrm{E} 046^{\circ} 53^{\prime} 07.4^{\prime \prime}\right)$ and Anjokipoty

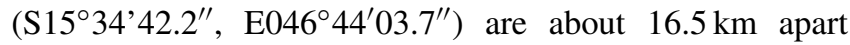
(Fig. 1c). Their location in the zone visited by the ITCZ (e.g., Nassor and Jury, 1998) makes them ideal sites to test the hypothesis that latitudinal migration of the ITCZ influenced the Holocene climate of NW Madagascar (e.g., Chiang and Bitz, 2005; Broccoli et al., 2006; Chiang and Friedman,
2012; Schneider et al., 2014). Mahajanga has a tropical savanna climate (Aw) according to the Köppen-Geiger climate classification, with a distinct wet summer (from October to April) and dry winter (May-September). The mean annual rainfall is around $1160 \mathrm{~mm}$. The mean maximum temperature in November, the hottest month in the summer, is about $32^{\circ} \mathrm{C}$. The mean minimum temperature in July, the coldest month of the dry winter, is about $18^{\circ} \mathrm{C}$ (Fig. 1b).

\subsection{Climate of Madagascar}

The climate of Madagascar is unique because of its varied topography and its position in the Indian Ocean (Supplement Figs. S1-S2; also see Jury, 2003; DGM, 2008; Douglas and Zinke, 2015, p. 281-299; Voarintsoa et al., 2017b, p. 138-139; Scroxton et al., 2017). Regionally distinct rainfall gradients from east to west and from north to south are evident across the country (Jury, 2003; Dewar and Richard, 2007), and these are linked to easterly trade winds in winter (May-October) and northwesterly tropical storms in summer, respectively. In NW Madagascar, summer rainfall is monsoonal and it is in phase with the seasonal southward migration of the ITCZ. The studies of Chiang and Bitz (2005) and Broccoli et al. (2006) have suggested that cooler-warmer intervals bring the ITCZ south-north; thus, regions in the tropical SH are wet-dry. Generally, the ITCZ migrates towards the Earth's warmer hemisphere (Frierson and Hwang, 2012; Kang et al., 2008; McGee et al., 2014; Sachs et al., 2009). In fact, longer-term ITCZ migration appears to have affected climate in NW Madagascar between ca. 370 and 800 CE (see Fig. 8 of Voarintsoa et al., 2017b). This relationship was inferred from changes in global climate conditions.

The climate of Madagascar is also influenced by changes in Indian Ocean sea surface temperature (SST) (Zinke et al., 2004; see also Kunhert et al., 2014) and changes in the Agulhas Current SST off southwestern Madagascar (Lutjeharms, 2006; Beal et al., 2011; Zinke et al., 2014). The most immediate signal is the Indian Ocean Dipole (IOD), or Indian Ocean zonal mode (Li et al., 2003; Zinke et al., 2004), but the El Niño-Southern Oscillation (ENSO) may also influence its climate (e.g., Brook et al., 1999). The IOD has been linked to Holocene climate variability in the tropical Indian Ocean (Abram et al., 2009; Tierney et al., 2013). However, its linkages to ENSO are still debated (e.g., Saji et al., 1999; Li et al., 2003; Lee and McPhaden, 2008; Brown et al., 2009; Schott et al., 2009; Shinoda et al., 2004; Venzke et al., 2000; Abram et al., 2008; Saji and Yagamata, 2003; Meyers et al., 2007). The complex interactions between these interannual climatic factors make them an ideal topic for further investigation using high-resolution records, and thus they will not be the focus of this paper. However, their possible effects are referred to briefly in Supplement text 4 . 


\subsection{The Holocene in NW Madagascar}

Little is hitherto known about Holocene climate change in NW Madagascar or about the major drivers of long-term climatic changes there. Most paleoclimate information from this region covers the last 2 millennia with more focus on the anthropogenic effects on the Malagasy ecosystems (e.g., Crowley and Samonds, 2013; Burns et al., 2016; Voarintsoa et al., 2017b). This is because several studies show that megafaunal extinctions in Madagascar coincide with the arrival of humans around 2-3 thousand (ka) BP (e.g., see Table 1 of Virah-Sawmy et al., 2010; MacPhee and Burney, 1991; Burney et al., 1997; Crowley, 2010). There are even fewer long-term paleoclimate records for the NW region, with only sediments from Lake Mitsinjo (3.5 ka BP; Matsumoto and Burney, 1994) and stalagmites from Anjohibe Cave (40 ka BP; Burney et al., 1997) providing records of more than 3000 years. Even though these records provide useful information about paleoenvironmental changes in NW Madagascar, links to global climatic changes, particularly the links to changes in ITCZ, are not yet fully understood.

\section{Methods}

\subsection{Radiometric dating}

A total of 22 samples were drilled from Stalagmite ANJB2 and 9 samples for Stalagmite MAJ-5 for U-series dating (Table S1 and S2). Each sampling trench is long $(\sim 5$ to $20 \mathrm{~mm})$, narrow $(\sim 1-2 \mathrm{~mm})$, and shallow $(\sim 1 \mathrm{~mm})$, allowing us to extract $50-250 \mathrm{mg}$ of $\mathrm{CaCO}_{3}$ powder. We followed the chemical procedures described in Edwards et al. (1987) and Shen et al. (2002) when separating uranium and thorium. $\mathrm{U} / \mathrm{Th}$ measurements were performed on the multi-collector inductively coupled plasma mass spectrometry (ICP-MS) of the University of Minnesota, USA, and on a similar instrument in the Stable Isotopes Laboratory of Xi' an, in Jiaotong, China. Instrument details are provided in Cheng et al. (2013). Corrected ${ }^{230} \mathrm{Th}$ ages assume an initial ${ }^{230} \mathrm{Th} /{ }^{232} \mathrm{Th}$ atomic ratio of $4.4 \pm 2.2 \times 10^{-6}$. This is the ratio for "bulk earth" or crustal material at secular equilibrium with a ${ }^{232} \mathrm{Th} /{ }^{238} \mathrm{U}$ value of 3.8. The uncertainty in the bulk earth value is assumed to be $\pm 50 \%$ (see footnotes to Tables S1 and S2 in the Supplement). The error in the final corrected age incorporates this uncertainty. The radiometric data are reported as years BP, where BP is before present, and "present" is AD 1950. Stalagmite chronologies were constructed using the StalAge1.0 algorithm of Scholz and Hoffman (2011) and Scholz et al. (2012), an algorithm using a Monte Carlo simulation. The algorithm can identify major and minor outliers and age inversions. The StalAge scripts were run on the statistics program $\mathrm{R}$ version 3.2.2. The age models were adjusted considering hiatal surfaces identified in the samples, using the approach of Railsback et al. (2013; see their Fig. 9).

\subsection{Petrography and mineralogy}

Petrography and mineralogy of the two stalagmites were investigated (1) by examining both the polished surfaces and the scanned images of the sectioned stalagmites, and by identifying any diagenetic fabrics (e.g., Zhang et al., 2014) that could potentially affect stable isotope values, (2) by observing 11 oversized thin sections $(50.8 \times 76.2 \mathrm{~mm})$ under the Leitz Laborlux 12 Pol microscope and the Leica DMLP equipped with QCapture in the Sedimentary Geochemistry Lab at the University of Georgia, (3) by using scanning electron microscopy (SEM) to better understand the mineralogical fabrics at locations of interest (Fig. S13), and (4) by analyzing about 30-100 mg of powdered spelean layers $(n=15)$ on a Bruker D8 X-ray diffractometer in the Department of Geology, University of Georgia. For calcite and aragonite identification, we used $\operatorname{CoK} \alpha$ radiation at a $2 \theta$ angle between 20 and $60^{\circ}$.

LSW of clearly defined layers was measured at selected locations on the stalagmite polished surfaces (Fig. S4; Sletten et al., 2013; Railsback et al., 2014; Voarintsoa et al., 2017b). LSW is the horizontal distance between two points on the flanks of the stalagmite where convexity is greatest. It is the width near the top of the stalagmite when the layer being examined was deposited. LSW is measured at right angles to the growth axis of the stalagmite; it is the horizontal distance between two points on the layer growth surface, at which a virtual line inclined at $35^{\circ}$ to the growth axis becomes tangent to the layer growth surface as shown in Fig. S4. LSW may vary along the growth axis of the stalagmite, with smaller values suggesting drier conditions and larger values wetter conditions.

\subsection{Stable isotopes}

Samples of $50-100 \mu \mathrm{g}$ were drilled along the stalagmite's growth axis for stable isotope analysis. The trench size is very small $(1.5 \times 0.5 \times 0.5 \mathrm{~mm})$. Since a small mixture of calcite and aragonite could potentially change the $\delta^{18} \mathrm{O}$ and $\delta^{13} \mathrm{C}$ of the measured spelean layers (see for example Frisia et al., 2002), drilling and sample extraction were carefully performed on individually discrete layers using the smallest drill-bit head (SSW-HP-1/4) to avoid potential mixing between calcite and aragonite. The polished surface of the two stalagmites was examined to see if features of diagenetic alteration are present (see for example Fig. 2 of Zhang et al., 2014), but none was found. During sampling, the mineralogy at the crest, where stable isotope samples were extracted, was recorded for future mineralogical correction.

Aragonite oxygen and carbon isotopic corrections were performed to compensate for aragonite's inherent fractionation of heavier isotopes (e.g., Romanek et al., 1992; Kim et al., 2007; McMillan et al., 2005) and to remove the mineralogical bias in isotopic interpretation between calcite and aragonite. The correction consists of subtracting $0.8 \%$ for 


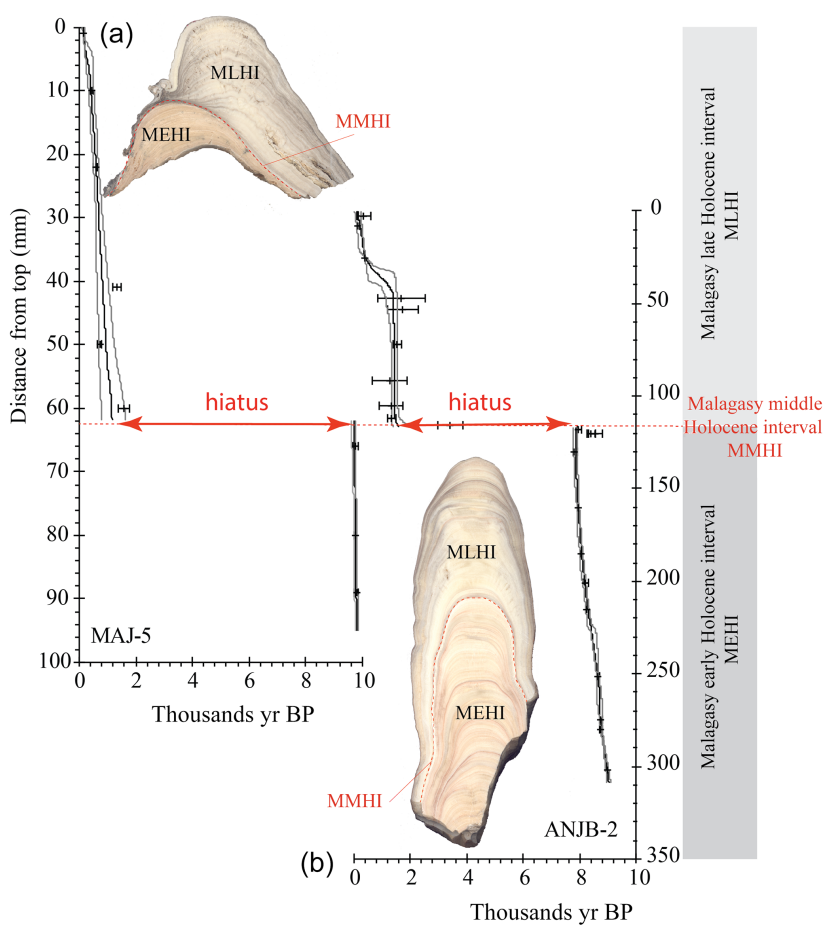

Figure 2. Age model of Stalagmites MAJ-5 (a) and ANJB-2 (b) using the StalAge1.0 algorithm of Scholz and Hoffman (2011) and Scholz et al. (2012). Scanned images of the two samples are shown for reference and to indicate the three distinct Holocene intervals.

$\delta^{18} \mathrm{O}$ (Kim and O’Neil, 1997; Tarutani et al., 1969; Kim et al., 2007; Zhang et al., 2014) and $1.7 \%$ for $\delta^{13} \mathrm{C}$ (Rubinson and Clayton, 1969; Romanek et al., 1992) for the aragonite, as has been carried out previously (e.g., Holmgren et al., 2003; Sletten et al., 2013; Liang et al., 2015; Railsback et al., 2016; Voarintsoa et al., 2017a), as shown in Eqs. (2) and (3) below (where $R_{\mathrm{A} / \mathrm{C}}$ is the aragonite percentage if not $100 \%)$.

$$
\begin{aligned}
& \delta^{18} \mathrm{O}_{\text {corr. }}(\%, \text {, VPDB })=\delta^{18} \mathrm{O}_{\text {uncorr. }} \text { (\%o, VPDB) } \\
& -\left[R_{\mathrm{A} / \mathrm{C}} \times 0.8(\%, \mathrm{VPDB})\right] \\
& \delta^{13} \mathrm{C}_{\text {corr. }}(\% \text {, VPDB })=\delta^{13} \mathrm{C}_{\text {uncorr. }}(\%, \text { VPDB }) \\
& -\left[R_{\mathrm{A} / \mathrm{C}} \times 1.7(\%, \mathrm{VPDB})\right]
\end{aligned}
$$

Supplement Figs. S6-S8 show both the corrected and uncorrected isotopic records.

For the analytical methods, oxygen and carbon isotope ratios were measured using the Finnigan MAT 253 mass spectrometer fitted with the Kiel IV Carbonate Device of the Xi' an Stable Isotope Laboratory in China (ANJB-2; $n=$ 654) and using the Delta V Plus at $50^{\circ} \mathrm{C}$ fitted with the GasBench isotope ratio mass spectrometer (IRMS) of the Alabama Stable Isotope Laboratory in USA (MAJ-5; $n=$ 286). Analytical procedures using the MAT 253 are identical to those described in Dykoski et al. (2005), with isotopic measurement errors of less than $0.1 \%$ for both $\delta^{13} \mathrm{C}$ and $\delta^{18} \mathrm{O}$. Analytical methods and procedures using the GasBench IRMS machine are identical to those described in Skrzypek and Paul (2006), Paul and Skrzypek (2007), and Lambert and Aharon (2011), with $\pm 0.1 \%$ errors for both $\delta^{13} \mathrm{C}$ and $\delta^{18} \mathrm{O}$. In both techniques, the results are reported relative to Vienna Pee Dee Belemnite (VPDB) and with standardization relative to NBS19. An inter-lab comparison of the isotopic results was conducted, and it involved replicating every 10th sample of Stalagmite MAJ-5 at both labs. This exercise showed a strong correlation between the lab results (Supplement Fig. S5).

\section{Results}

\subsection{Radiometric data}

Results from radiometric analyses of the two stalagmites are presented in Tables $\mathrm{S} 1$ and $\mathrm{S} 2$. Corrected ${ }^{230} \mathrm{Th}$ ages suggest that Stalagmite ANJB-2 was deposited between ca. $8977 \pm 50$ and ca. $161 \pm 64$ years BP, and Stalagmite MAJ-5 was deposited between ca. $9796 \pm 64$ and ca. $150 \pm 24$ years BP. These ages collectively indicate stalagmite deposition at the beginning (between ca. 9.8 and $7.8 \mathrm{ka} \mathrm{BP}$ ) and at the end of the Holocene (after ca. 1.6 ka BP). In both stalagmites, the older ages have small $2 \sigma$ errors and they generally fall in correct stratigraphic order, except sample ANJB-2-120 and its replicate ANJB-2-120R, which were not used because of the sample's high porosity and high detritus content. In contrast, many of the younger ages have larger uncertainties. This is mainly because many of the younger samples have very low uranium concentration and the detrital thorium concentration is also high, similar to what Dorale et al. (2004) reported. We also understand that the value for initial ${ }^{230} \mathrm{Th}$ correction, i.e., the initial ${ }^{230} \mathrm{Th} /{ }^{232} \mathrm{Th}$ atomic ratio of $4.4 \pm 2.2 \times 10^{-6}$ for a bulk earth with a ${ }^{232} \mathrm{Th} /{ }^{238} \mathrm{U}$ value of 3.8 , in these samples could have slightly altered the ${ }^{230} \mathrm{Th}$ age of these younger samples, leading to larger uncertainties (such as discussed in Lachniet et al., 2012). We encountered similar problems while working on other younger samples from the same cave, but we compared the stable isotope profile with other published records using isochron dating methods, and results did not differ significantly (see Fig. 9 of Voarintsoa et al., 2017b). Since this work does not focus on decadal or centennial interpretation of the late Holocene stable isotope data, additional chronology adjustment has not been made, and we used the chronology from StalAge to construct the time series. However, in Figs. 5 and 6, age uncertainties are given below the stable isotope profiles so that comparisons with other records can accommodate these uncertainties.

The key finding from our age and petrographic data for the two stalagmites is that they indicate three distinct intervals of growth and nongrowth during the Holocene (Figs. 2$4,7)$. The evidence for this includes (1) $\mathrm{CaCO}_{3}$ deposition between ca. 9.8 and $7.8 \mathrm{ka} \mathrm{BP},(2)$ a long depositional hiatus between ca. 7.8 and $1.6 \mathrm{ka} \mathrm{BP}$, and (3) resumption of $\mathrm{CaCO}_{3}$ 


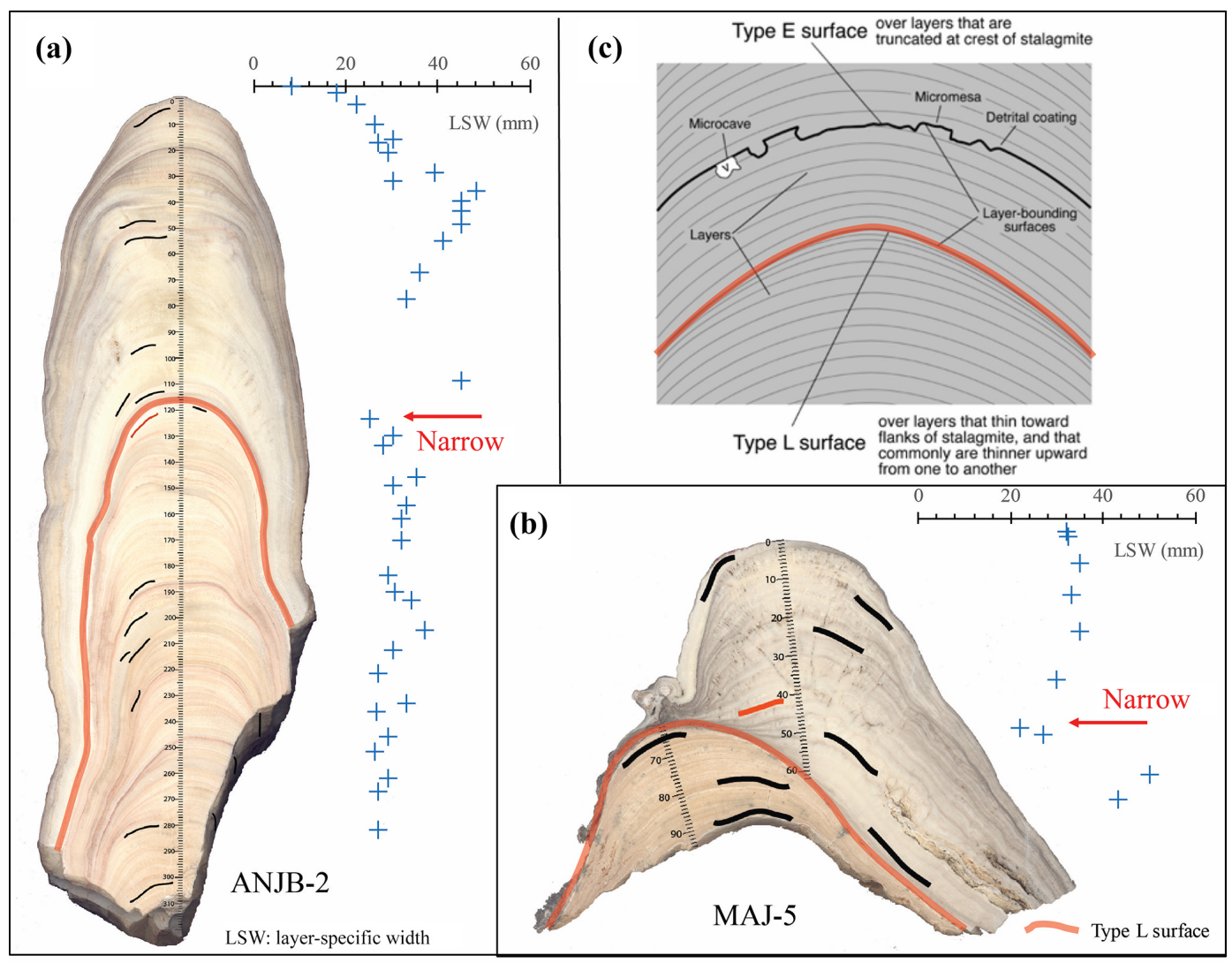

Figure 3. (a) Scanned image of Stalagmite ANJB-2 and the corresponding variations in layer-specific width (LSW). (b) Scanned image of Stalagmite MAJ-5 and the corresponding layer-specific width (LSW). (c) Sketches of typical layer-bounding surfaces (Type E and Type L) of Railsback et al. (2013). Close-up photographs of the hiatuses are shown in Fig. S6.

deposition after ca. $1.6 \mathrm{ka}$ BP. In the rest of the paper, we will refer to these intervals as the Malagasy early Holocene interval (MEHI), Malagasy mid-Holocene interval (MMHI), and Malagasy late Holocene interval (MLHI), respectively.

\subsection{Stable isotopes}

Raw values of $\delta^{18} \mathrm{O}$ and $\delta^{13} \mathrm{C}$ for Stalagmite ANJB-2 range from -8.9 to $-2.3 \%$ (mean $=-5.0 \%$ ) and from -11.0 to $+5.2 \%$ (mean $=-4.2 \%$ ) , respectively, relative to VPDB. Raw values of $\delta^{18} \mathrm{O}$ and $\delta^{13} \mathrm{C}$ for Stalagmite MAJ-5 range from -8.8 to $-0.9 \%$ (mean $=-4.9 \%$ ) and from -9.4 to $+2.6 \%$ (mean $=-4.4 \%$ ) , respectively, relative to VPDB. Mean $\delta^{18} \mathrm{O}$ and $\delta^{13} \mathrm{C}$ values are distinguishable between the MEHI and the MLHI. In both stalagmites, the amplitude of $\delta^{18} \mathrm{O}$ fluctuations was fairly constant throughout the Holocene; whereas the $\delta^{13} \mathrm{C}$ records show a dramatic shift toward higher values (i.e., from -10.9 to $+3.8 \%$, VPDB) at ca. $1.5 \mathrm{ka} \mathrm{BP}$.

The MEHI and MLHI are isotopically distinct (Fig. 4). The MEHI is characterized by statistically correlated $\delta^{18} \mathrm{O}$ and $\delta^{13} \mathrm{C}\left(r^{2}=0.65\right.$ and 0.53$)$ and much depleted $\delta^{13} \mathrm{C}$ values (ca. -11.0 to $-4.0 \%$ ). A prominent isotopic excursion is evident between ca. 8.1 and ca. $8.3 \mathrm{kaBP}$ (Fig. 5), when stalagmite $\delta^{18} \mathrm{O}$ and $\delta^{13} \mathrm{C}$ ratios reach their lowest values of -6.8 and $-10.9 \%$, respectively. In contrast to the MEHI, the values of $\delta^{18} \mathrm{O}$ and $\delta^{13} \mathrm{C}$ during the MLHI are poorly correlated $\left(r^{2}=0.25\right.$ and 0.17$)$, and $\delta^{13} \mathrm{C}$ values are more enriched (Figs. 4, 6). Since Stalagmites ANJB-2 and MAJ-5 were collected from two different caves, $16 \mathrm{~km}$ apart, it is not surprising to see discrepancies between the stable isotopes during similar intervals, suggesting that local karst conditions could be one of the discrepancy factors. Another potential source for the discrepancy is the larger uncertainty of the younger ages due to low uranium and high detrital concentrations. This U-Th aspect has been a challenge for several young stalagmites (e.g., Dorale et al., 2004; Lachniet et al., 2012) including samples from NW Madagascar (this study). While the utility of speleothems as a climate proxy largely depends on replication of stable isotope values, this study specifically highlights the replication of stalagmite deposition and nondeposition and the isotopic characteristics of each depositional interval of the Holocene. 


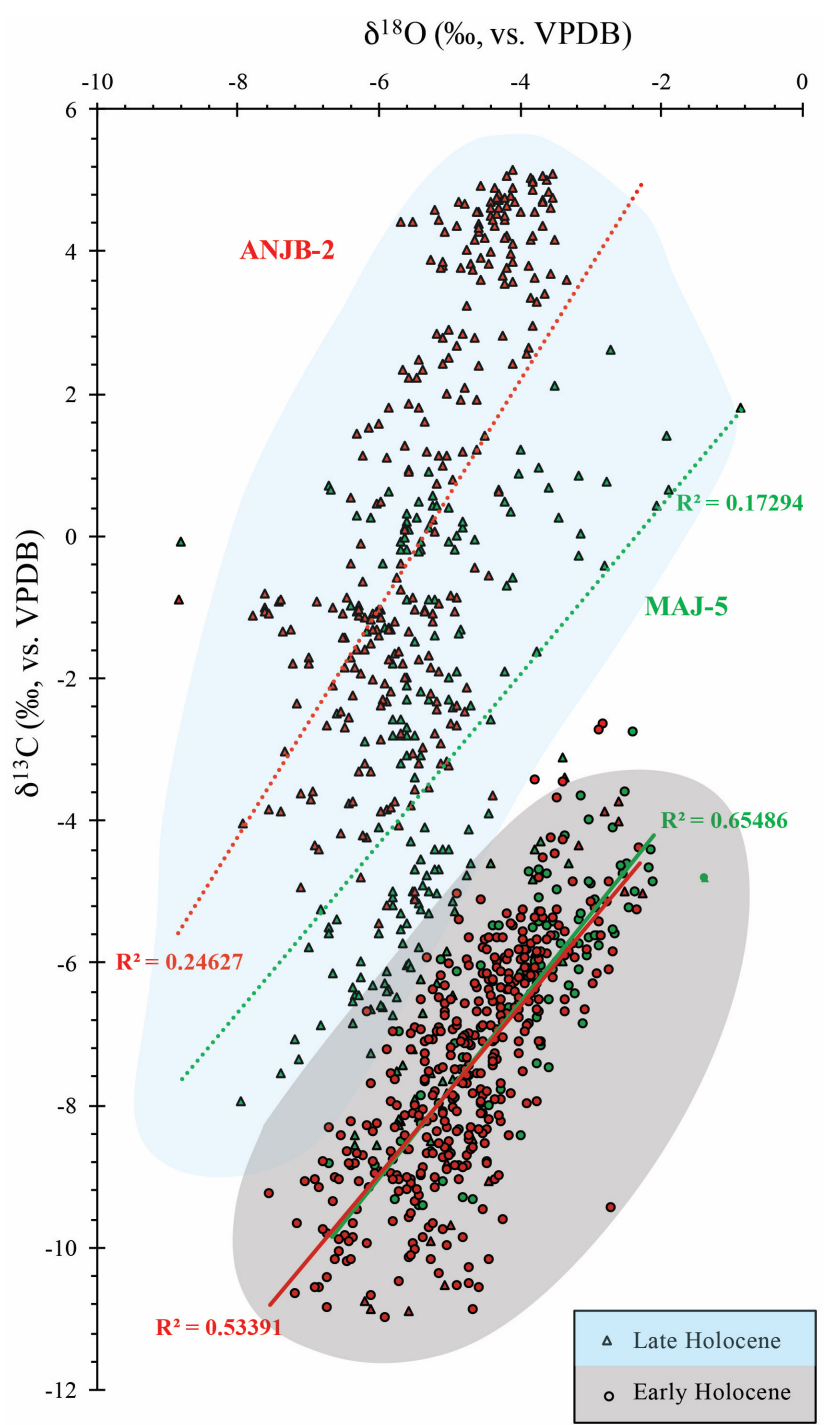

Figure 4. Stable isotope data. Scatter plots of $\delta^{13} \mathrm{C}$ and $\delta^{18} \mathrm{O}$ for Stalagmites MAJ-5 (green) and ANJB-2 (red) during the Malagasy early Holocene interval (circle) and the Malagasy late Holocene interval (triangle). The plot shows distinctive early and late Holocene conditions (roughly highlighted in gray and light blue, respectively).

\subsection{Mineralogy, petrography, and layer-specific width}

In both stalagmites ANJB-2 and MAJ-5, the hiatus of deposition is characterized by a well-developed Type L surface (Figs. 2, 3, S15). Petrography and mineralogy are distinct before and after this hiatus (Figs. 3, 5-6). Below the hiatus, laminations are well preserved in both stalagmites. Above the hiatus, laminations are not well preserved, although noted in some intervals.

In Stalagmite ANJB-2, LSW varies from 37 to $26.5 \mathrm{~mm}$ with a mean of $30 \mathrm{~mm}$. It decreases to $28 \mathrm{~mm}$ at the hiatus (Fig. 3). The mineralogy is dominated by aragonite below the hiatus, although there are also a few thick layers of primary calcite. A thin $(\sim 2-3 \mathrm{~mm})$ layer of white, very soft, and porous aragonite is identified just below the hiatus (Fig. S15). Above the hiatus, layers are also calcite and aragonite, with calcite dominant, and the calcite layers contain macro-cavities that are mostly off-axis macroholes (ShtoberZisu et al., 2012).

As noted in previous Sect. 4.2, there is a prominent isotopic excursion at ca. $8.2 \mathrm{ka} \mathrm{BP}$, and this excursion is in the calcite layer in Stalagmite ANJB-2 at 195-202 mm from its top. X-ray diffraction spectrum from this layer suggests that the mineralogy is $100 \%$ calcite (Figs. S14, S16-S17). We believe the calcite to be primary and not a diagenetic product of aragonite for three reasons. First, the laminations in the thick layer of calcite were not altered (Figs. S16-S17). Second, the polished surface of the stalagmite shows no evidence of fiber relicts and textural ghosts such as observed in Juxtlahuaca Cave in southwestern Mexico (Lachniet et al., 2012) and in Shennong Cave in southeastern China (Zhang et al., 2014). Third, petrographic comparison with known examples of primary and secondary calcite observed under microscope (e.g., Railsback, 2000; Perrin et al., 2014) suggests that there is no strong evidence of aragonite-to-calcite transformation.

In Stalagmite MAJ-5, LSW varies from 50 to $22 \mathrm{~mm}$ with a mean of $35.5 \mathrm{~mm}$. It decreases to $22 \mathrm{~mm}$ at the hiatus (Fig. 3). Below the hiatus, mineralogy is an even mixture between calcite and aragonite. Above the hiatus, mineralogy is mainly calcite, except the uppermost $2 \mathrm{~mm}$ in which mineralogy is $75 \%$ calcite and $25 \%$ aragonite. Macro-cavities are also present throughout this upper part of Stalagmite MAJ-5.

\subsection{Summary of results}

The various proxy climate records from Stalagmites ANJB-2 and MAJ-5 suggest three distinct climate and/or hydrological intervals during the Holocene. The MEHI (ca. 9.8 to $7.8 \mathrm{ka} \mathrm{BP}$ ), with evidence of stalagmite deposition, is characterized by statistically correlated $\delta^{18} \mathrm{O}$ and $\delta^{13} \mathrm{C}\left(r^{2}=0.65\right.$ and 0.53 ) and more negative $\delta^{13} \mathrm{C}$ values (ca. -11.0 to $-4.0 \%$ ). The MMHI (ca. 7.8 to $1.6 \mathrm{ka} \mathrm{BP}$ ) is marked by a long-term hiatus in deposition, which is preceded by a welldeveloped Type L surface in both Stalagmites ANJB-2 and MAJ-5 (Figs. 3, S15). The Type L surface is observed as an upward narrowing of stalagmite width and layer thickness. It is best developed in Stalagmite MAJ-5 (Fig. S15). In Stalagmite ANJB-2, the hiatus at the Type L surface is additionally preceded by a ca. $3 \mathrm{~mm}$ thick layer of highly porous, very soft, and fibrous white crystals of aragonite (the only aragonite with such properties). This aragonite is topped by a thin and well-defined layer of detrital materials (Fig. S15), further evidence of a hiatus. Finally, the MLHI (after ca. $1.6 \mathrm{kaBP}$ ) is characterized by poorly correlated $\delta^{18} \mathrm{O}$ and $\delta^{13} \mathrm{C}\left(r^{2}=0.25-0.17\right)$, and by a marked shift toward higher $\delta^{13} \mathrm{C}$ values (Figs. 4, 6). 


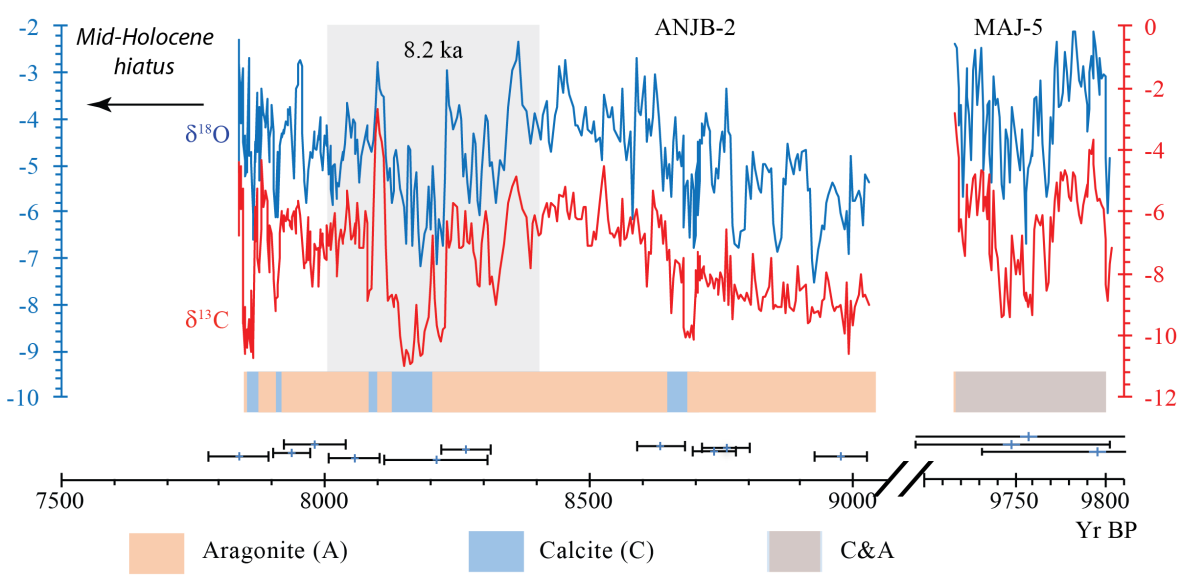

Figure 5. Variations in $\delta^{13} \mathrm{C}, \delta^{18} \mathrm{O}$, and mineralogy in Stalagmite ANJB-2 and Stalagmite MAJ-5 during the Malagasy early Holocene interval. Supplement Fig. S6 shows both the corrected and uncorrected isotope values.

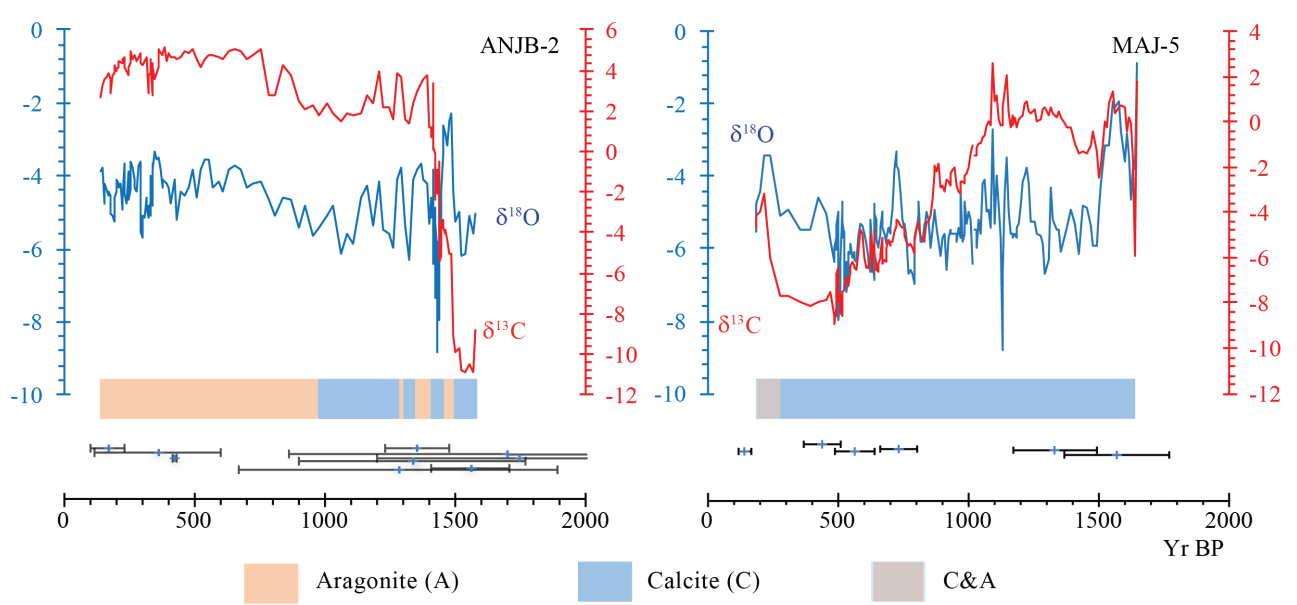

Figure 6. Variations in $\delta^{13} \mathrm{C}, \delta^{18} \mathrm{O}$, and mineralogy in Stalagmite ANJB-2 and Stalagmite MAJ-5 during the Malagasy late Holocene interval. Supplementary Fig. S7 shows both the corrected and uncorrected isotope values, and Fig. S8 compares the corrected $\delta^{18} \mathrm{O}$ values for both stalagmites.

\section{Discussion}

\subsection{Paleoclimate significance of stalagmite growth and nongrowth: implications for paleohydrology}

Growth and nongrowth of stalagmites depends on several factors linked to water availability, which is largely determined by climate (more water during warm-rainy seasons and less water during cold-dry seasons). Water is the main dissolution and transporting agent for most chemicals in speleothems. Cave hydrology varies significantly over time in response to climate, and this variability influences the formation or dissolution of $\mathrm{CaCO}_{3}$. In this regard, calcium carbonate does not form if there is little or no water entering the cave, or if there is too much (see Sect. 2.1). Absence of groundwater recharge most typically occurs during extremely dry conditions, whereas excessive water input to the cave occurs during extremely wet conditions. In the lat- ter scenario, water is undersaturated and flow rates are too fast to allow degassing. Often, water availability is reflected in the extent of vegetation above and around the cave, as plants require soil moisture or shallow groundwater to survive and propagate, and this contributes to the stalagmites' processes of formation. The link between stalagmite growthnongrowth, cave drip water, and soil $\mathrm{CO}_{2}$ is broadly influenced by changes in climate.

Major hiatuses in stalagmite deposition could be marked by a variety of features, including the presence of erosional surfaces, chalkification, dirt bands and/or detrital layers, offsetting of the growth axis, and/or sometimes by color changes (e.g., Holmgren et al., 1995; Dutton et al., 2009; Railsback et al., 2013, 2015; Voarintsoa et al., 2017a). Railsback et al. (2013) were able to identify significant features in stalagmites that allow distinction between nondeposition during extremely wet conditions (Type E surfaces) and non- 

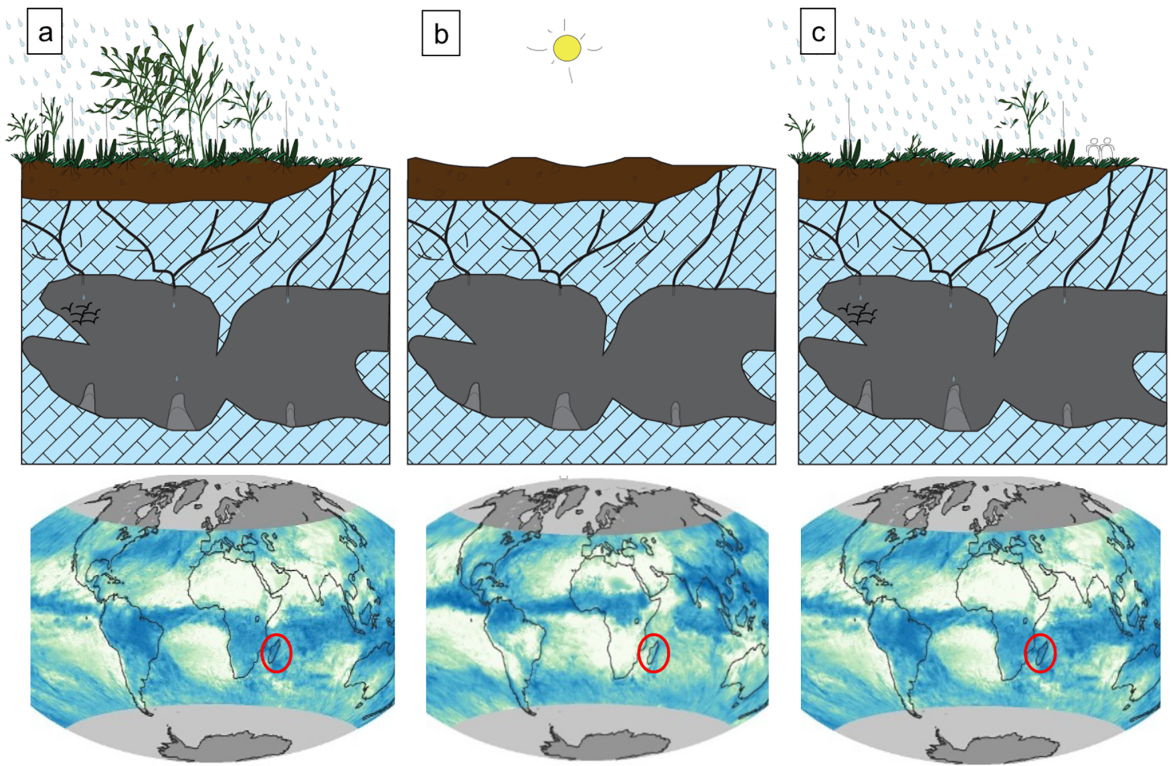

Figure 7. Simplified models portraying Holocene climate change in NW Madagascar and the possible climatic conditions linked to the ITCZ. (a) Wetter conditions during the early Holocene with the ITCZ further south (prior to ca. $7.8 \mathrm{ka} \mathrm{BP}$ ), favorable for stalagmite deposition. (b) Periodic dry conditions during the mid-Holocene (between ca. 7.8 and $1.6 \mathrm{ka} \mathrm{BP}$ ) with the ITCZ further north leading to no stalagmite formation (refer to Sect. 5.2.2). (c) Wetter conditions during the late Holocene (after ca. $1.6 \mathrm{ka} \mathrm{BP}$ ) with the ITCZ further south, favorable for stalagmite deposition. Drawings are not to scale. The bottom figures are from the same source as Fig. 1a, and they are only used here to give a perspective of the possible position of the ITCZ during the early, mid, and late Holocene. Madagascar is indicated with a red ellipse.

deposition during extremely dry conditions (Type L surfaces; Fig. 3). Physical properties of stalagmites that are evidence of extreme dry and wet events are summarized in Table 1 of Railsback et al. (2013) and the mechanisms are explained in their Fig. 5.

Type E surfaces are layer-bounding surfaces between two spelean layers when the underlying layers show evidence of truncation. The truncation results from dissolution or erosion (thus the name "E") of previously formed stalagmite layers by abundant undersaturated water. Type E surfaces are commonly capped with a layer of calcite (Railsback et al., 2013). This mineralogical trend is not surprising as calcite commonly forms under wetter conditions (e.g., Murray, 1954; Pobeguin, 1965; Siegel, 1965; Thrailkill, 1971; Cabrol and Coudray, 1982; Railsback et al., 1994; Frisia et al., 2002). Additionally, non-carbonate detrital materials are commonly abundant with varying grain size (i.e., from silt to sand size; Railsback et al., 2013).

Type L surfaces, however, are layer-bounding surfaces where the layers become narrower upward and thinner towards the flanks of the stalagmite. Decreases in layer thickness and stalagmite width upward are indications of lessening deposition (thus the name "L"; Railsback et al., 2013). Aragonite is a very common mineralogy below a Type L surface, especially in warmer settings. Layers of aragonite commonly form under drier conditions (Murray, 1954; Pobeguin, 1965; Siegel, 1965; Thrailkill, 1971; Cabrol and Coudray, 1982; Railsback et al., 1994; Frisia et al., 2002). Non- carbonate detrital materials are scarce, and if present, they tend to form a very thin horizon of very fine dust material (Railsback et al., 2013). Identification of Type L surfaces is aided by measuring the LSW (e.g., Sletten et al., 2013; Railsback et al., 2014; Fig. S4).

\subsection{Holocene climate in NW Madagascar}

The age models and petrographic features of Stalagmites ANJB-2 and MAJ-5 suggest three distinct Holocene climate intervals (MEHI, MMHI, and MLHI; see Sect. 4.1) in NW Madagascar. Possible conditions during these intervals are illustrated in the sketches of Fig. 4.

\subsubsection{Malagasy early Holocene interval (ca. 9.8-7.8 ka BP)}

Stalagmite deposition during the early Holocene suggests that the chambers where Stalagmites ANJB-2 and MAJ-5 were collected were sufficiently supplied with water to allow $\mathrm{CaCO}_{3}$ precipitation, in accord with Eq. (1). This in turn implies relatively wet conditions that could indicate longer summer rainy seasons relative to modern climate, or wet years in NW Madagascar. The correlative $\delta^{13} \mathrm{C}$ and $\delta^{18} \mathrm{O}$ values further suggest that vegetation consistently responded to changes in moisture availability, which in turn was dependent on climate. 
The prominent negative $\delta^{18} \mathrm{O}$ and $\delta^{13} \mathrm{C}$ excursions in Stalagmite ANJB-2 (Sect. 4.2; Figs. 5 and 10) are parallel to the $\delta^{18} \mathrm{O}$ excursion of the Greenland ice core records at ca. $8.2 \mathrm{kaBP}$ (e.g., Alley et al., 1997). The decrease in $\delta^{18} \mathrm{O}$ and $\delta^{13} \mathrm{C}$ values and the presence of calcite mineralogy at the same interval combine to suggest a wet $8.2 \mathrm{kaBP}$ event in NW Madagascar. The $8.2 \mathrm{ka} \mathrm{BP}$ event was triggered by a release of freshwater from the melting Laurentide Ice Sheet into the North Atlantic basin, bringing cooler conditions in several Northern Hemisphere (NH) regions (e.g., Alley et al., 1997; Barber et al., 1999), and via global teleconnections, this may have affected climate in NW Madagascar (see Sect. 5.5).

The MEHI terminated when conditions became much drier, as suggested by increasing $\delta^{18} \mathrm{O}$ and $\delta^{13} \mathrm{C}$ values in Stalagmite ANJB-2, by decreasing LSW in both stalagmites, and by the presence of major Type L surfaces in both stalagmites. The thin (ca. $3 \mathrm{~mm}$ ), porous, and white aragonite layer in Stalagmite ANJB-2, a very similar deposit to that described in Niggemann et al. (2003), suggests that the terminal drought was at times severe. Aragonite is a $\mathrm{CaCO}_{3}$ polymorph that forms preferentially under drier conditions (Murray, 1954; Pobeguin, 1965; Siegel, 1965; Thrailkill, 1971; Cabrol and Coudray, 1982; Railsback et al., 1994; Frisia et al., 2002). The porous aragonite layer in Stalagmite ANJB-2 is capped by a very thin layer of non-carbonate, brown detritus, which may have been transported to the stalagmite as an aerosol and accumulated on the dry stalagmite surface over time. Accumulation of the detritus must take place in the absence of drip water (e.g., Railsback et al., 2013). A shift to drier conditions is also supported by isotopic data from Stalagmite ANJ94-5 from Anjohibe Cave (Wang and Brook, 2013; Wang, 2016) in which relatively low $\delta^{13} \mathrm{C}$ and $\delta^{18} \mathrm{O}$ values prior to $7.6 \mathrm{ka} \mathrm{BP}$ give way to episodically greater values thereafter.

\subsubsection{Malagasy mid-Holocene interval (ca. 7.8-1.6 ka BP)}

The MMHI was a long $(\sim 6.5 \mathrm{ka})$ depositional hiatus in both stalagmites (Figs. 2-3), potentially suggesting dry conditions. The question is why did neither stalagmite grow during the MMHI? Here, we try to explain the factors and the climatic conditions that may have been responsible.

The documented severe dry conditions at the end of the MEHI (see Sect. 5.2.1) could have had a significant influence (1) on the cave hydrological system (e.g., Fig. 5 of Asrat et al., 2007; Bosák, 2011), such as the water conduits (primary or secondary porosity) to the chambers, and (2) on the vegetation cover above the caves, particularly above the chambers where Stalagmites ANJB-2 and MAJ-5 were collected. On the one hand, it is possible that the dry conditions late in the MEHI not only brought lesser water recharge to the cave, but also lowered the hydraulic head, and increased the rate of evapotranspiration in the vadose zone. This condi- tion possibly allowed more air to penetrate the aquifer, perhaps enhancing prior carbonate precipitation (PCP) in pores and conduits above the caves (e.g., Fairchild and McMillan, 2007; Fairchild et al., 2000; Johnson et al., 2006; Karmann et al., 2007; McDonald et al., 2007). This process must have blocked water moving towards Stalagmites ANJB2 and MAJ-5. On the other hand, the late MEHI drying trend (Sect. 5.2.1) could have challenged vegetation to grow, and we assume that some areas above Anjohibe and Anjokipoty caves must have been devoid of vegetation. Consequently, biomass activities could have been reduced. Because vegetation contributes $\mathrm{CO}_{2}$ to the carbonic acid dissolving $\mathrm{CaCO}_{3}$, its absence in certain areas above the cave could decrease the $\mathrm{pH}$ of the percolating water, and perhaps dissolution did not occur. Under these conditions, even if water reached the stalagmites, it may not have precipitated carbonate.

Whatever factors were responsible for the long-term depositional hiatus in Stalagmites ANJB-2 and MAJ-5, we believe that the hiatus was caused by disturbances to water catchments that feed the chambers at Anjohibe and Anjokipoty caves. The disturbances could be inherited from the very dry conditions at the end of the MEHI, and/or due to the lack of water supply, perhaps associated with an increase in epikarst ventilation, and/or by the absence of vegetation. Water and vegetation are two components of the karst system that play an important role in $\mathrm{CaCO}_{3}$ dissolution and precipitation (see Eq. 1). Their disturbance may have limited limestone dissolution in the epikarst and then carbonate precipitation in the cave zone.

Other evidence supports the idea of at least episodic dryness during the MMHI. A study on a $2 \mathrm{~m}$ long stalagmite (ANJ94-5) from Anjohibe Cave suggests episodic dryness during the MMHI and a depositional hiatus around the time when Stalagmites ANJB-2 and MAJ-5 stopped growing (Wang and Brook, 2013; Wang, 2016). For regional comparison, dry spells were also felt in central and southeastern Madagascar (e.g., Gasse and Van Campo, 1998; VirahSawmy et al., 2009).

In summary, several lines of evidence suggest a relatively drier climate in NW Madagascar during the MMHI compared to the MEHI. Drier intervals generally imply drier summer seasons with less rainfall (Fig. 8), perhaps reflecting shorter visits by the ITCZ. In this regard, even though the region received rainfall, the necessary conditions could not have been attained to activate the growth of Stalagmites ANJB-2 and MAJ-5, thus the hiatuses.

\subsubsection{Malagasy late Holocene interval (ca. 1.6 ka BP-present)}

Resumption of stalagmite deposition after ca. $1.6 \mathrm{ka}$ BP suggests a wetter climate in NW Madagascar with reactivation of the previous epikarst hydrologic system. Climatic conditions must have been similar to those of the early Holocene. The sudden beginning of stalagmite growth during the MLHI 


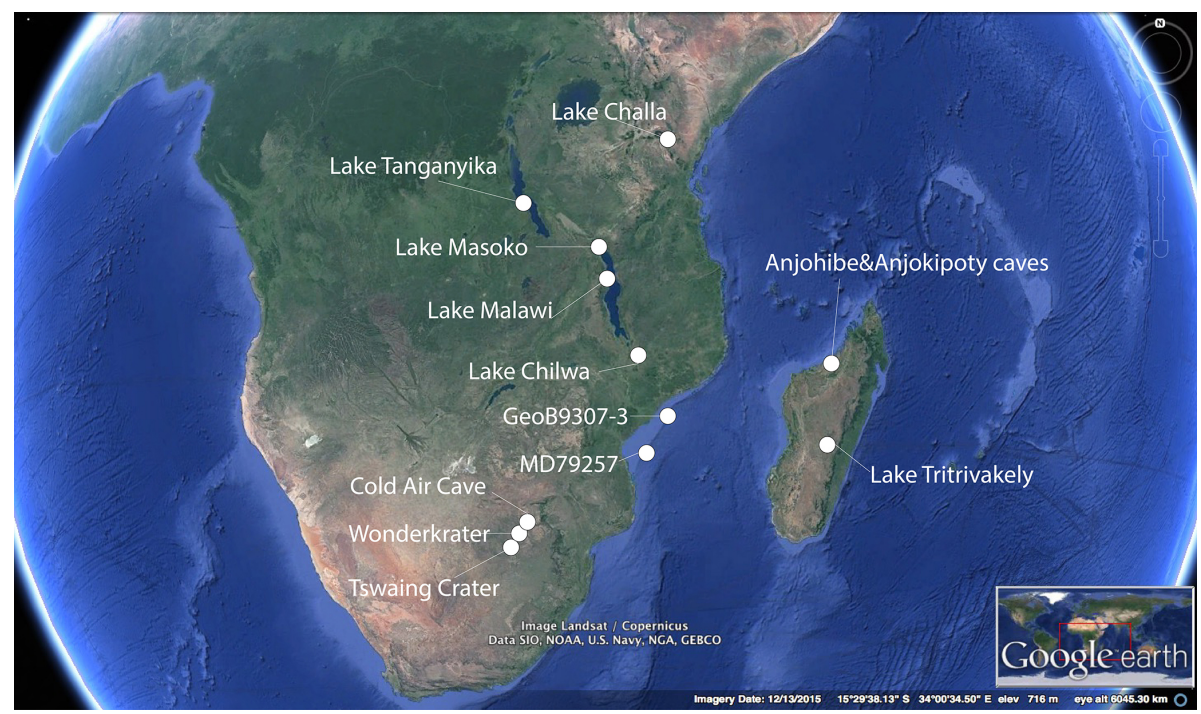

Figure 8. Regional comparison. Google Earth image showing the location of sites reported in Table S3 and in Fig. 9. Most site records are from lake sediments, except for GeoB9307-3 (onshore off delta sediments), MD79257 (alkenone from marine sediment core), and Cold Air, Anjohibe, and Anjokipoty caves (stalagmites $\delta^{18} \mathrm{O}$ ).

and the large $\delta^{13} \mathrm{C}$ shift from depleted to enriched values at ca. $1.5 \mathrm{ka} \mathrm{BP}$ (Fig. 6) after such long hiatuses may have been associated with changes in vegetation cover above the cave linked to human activities (e.g., Burns et al., 2016; Crowley and Samonds, 2013; Crowther et al., 2016; Voarintsoa et al., 2017b). Lower $\delta^{13} \mathrm{C}$ values in Stalagmite MAJ-5 after $0.8 \mathrm{ka}$ BP (Fig. 3), compared to higher values in Stalagmite ANJB-2, may suggest different local karst conditions, either natural, human-induced, or something else, at each site. Further investigations will be necessary to better understand this.

\subsection{Holocene climate in NW Madagascar: implications for ITCZ dynamics}

In NW Madagascar, stalagmite deposition during the MEHI and the MLHI suggests there was sufficient drip water for stalagmite growth and therefore wetter conditions. This may indicate a more southerly mean position of the ITCZ. Factors that could influence the mean position of the ITCZ include changes in insolation (e.g., Haug et al., 2001; Wang et al., 2005; Cruz et al., 2005; Fleitmann et al., 2003, 2007; Schefuß et al., 2005; Suziki, 2011; Kutzbach and Liu, 1997; Partridge et al., 1997; Verschuren et al., 2009; Voarintsoa et al., 2017a) and difference in temperature between the two hemispheres (e.g., Chiang and Bitz, 2005; Broccoli et al., 2006; Chiang and Friedman, 2012; Kang et al., 2008; McGee et al., 2014; Talento and Barreiro, 2016).

In contrast, the depositional hiatuses during the MMHI could suggest overall drier conditions, and thus a northward migration of the mean ITCZ. It may agree with the paleoclimate simulation of Braconnot et al. (2007), although the simulation is shorter term than the MMHI hiatus, but additional paleoclimate records are needed to improve its spatial and temporal resolution. A northward shift in the mean position of the ITCZ is consistent with drier conditions in the southern tropics, e.g., a weaker South American summer monsoon (Cruz et al., 2005; Seltzer et al., 2000; Wang et al., 2007; but see also Fig. 9 of Zhang et al., 2013), and with wetter conditions in the northern tropics (e.g., Dykoski et al., 2005; Fleitmann et al., 2007; Gasse, 2000; Haug et al., 2001; Weldeab et al., 2007; Zhang et al., 2013).

\subsection{Regional comparisons}

Records from neighboring locations (Figs. 8-9; Table S3) show that the Holocene wet-dry-wet succession reported here for NW Madagascar also affected other locations. For example, hydrogen isotope compositions of the n-C31 alkane in GeoB9307-3 from a $6.51 \mathrm{~m}$ long marine sediment core retrieved about $100 \mathrm{~km}$ off the Zambezi delta show a similar wet-dry-wet climate during early, middle, and late Holocene, respectively (Schefuß et al., 2011). These changes correspond to changes in temperature from $\sim 26.5$ to 27.25 to $27^{\circ} \mathrm{C}$, respectively, in the Mozambique Channel, as suggested by alkenone SST records from sediment cores MD79257 (Bard et al., 1997; Sonzogni et al., 1998). The Zambezi catchment is specifically relevant here because it is located at the southern boundary of the modern ITCZ, and so has a similar climatic setting as NW Madagascar, and its sensitivity to the latitudinal migration of the ITCZ could parallel that of Madagascar. Likewise, temperature reconstruction from the Mozambique Channel could be used to link regional changes in paleorainfall with regional changes in temperature. A general overview of the Holocene climate 


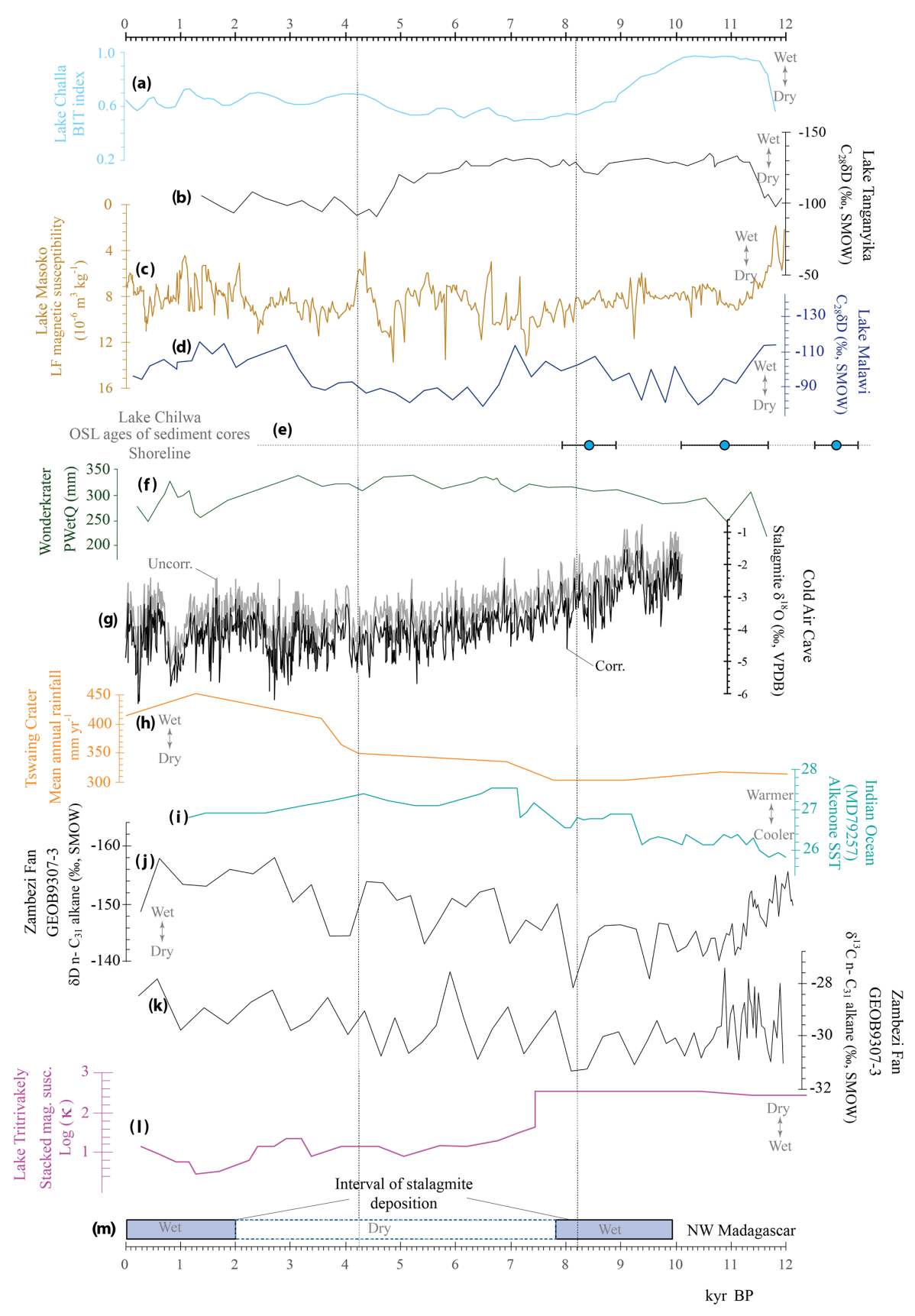

Figure 9. Regional comparison. (a) Lake Challa BIT index (Verschuren et al., 2009). (b) Lake Tanganyika $\mathrm{C}_{28} \delta \mathrm{D}$ (Tierney et al., 2008, 2010). (c) Lake Masoko low field magnetic susceptibility $\left(10^{-6} \mathrm{~m}^{3} \mathrm{~kg}^{-1}\right.$ ) (Garcin et al., 2006). (d) Lake Malawi C 28 D (Konecky et al., 2011 ). (e) Lake Chilwa OSL dates of shoreline (Thomas et al., 2009). (f) Wonderkrater reconstructed paleoprecipitation, PWetQ (precipitation of the wettest quarter; Truc et al., 2013). (g) Cold Air Cave corrected (corr.) and uncorrected (uncorr.) $\delta^{18}$ O profiles from Stalagmite T8 (Holmgren et al., 2003). (h) Tswaing Crater paleorainfall derived from sediment composition (Partridge et al., 1997). (i) Indian Ocean SST records from alkenone (Bard et al., 1997; Sonzogni et al., 1998). (j-k) Zambezi $\delta \mathrm{D} n-\mathrm{C}_{31}$ alkane and $\delta^{13} \mathrm{C}$ n-C 31 alkane (Schefuß et al., 2011). (l) Lake Tritrivakely stacked magnetic susceptibility (Williamson et al., 1998). (m) NW Madagascar (Anjohibe and Anjokipoty) interval of deposition of Stalagmite ANJB-2 and Stalagmite MAJ-5 (this study). The two vertical dashed lines indicate the boundary of the early, middle, and late Holocene by Walker et al. (2012) and Head and Gibbard (2015). 


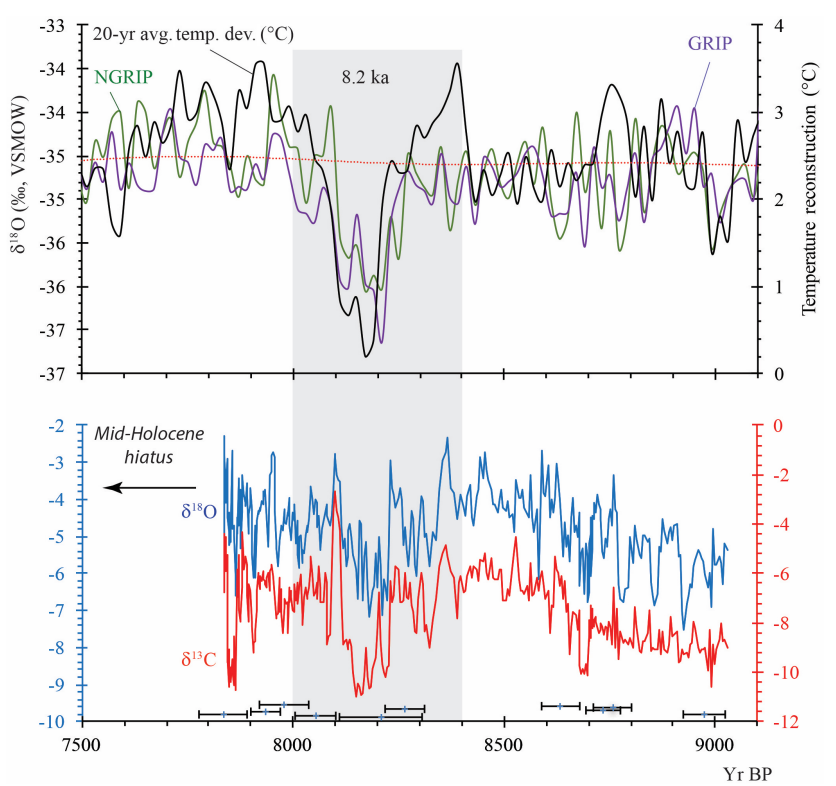

Figure 10. The $8.2 \mathrm{ka} \mathrm{BP}$ event in Madagascar. Oxygen isotope record from Greenland (GRIP and NGRIP) ice cores (Vinther et al., 2009) compared with Stalagmite ANJB-2 $\delta^{18} \mathrm{O}$ and $\delta^{13} \mathrm{C}$.

in the African locations neighboring Madagascar suggests a roughly consistent wetter and drier climate during the early and middle Holocene, respectively (Fig. 9, Table S3, also see Gasse, 2000; Singarayer and Burrough, 2015). However, late Holocene paleoclimate reconstructions vary. A simple explanation to this late Holocene variability is unlikely, but several interacting factors, including the latitudinal migration of the ITCZ, changes in ocean oscillations and sea surface temperatures, volcanic aerosols, and anthropogenic influences may have played a role (e.g., Nicholson, 1996; Gasse, 2000; Tierney et al., 2008; Truc et al., 2013). Assessing these factors is beyond the scope of this study.

\subsection{The 8.2 ka BP event in Madagascar: linkage to ITCZ and $\mathrm{AMOC}$}

The $8.2 \mathrm{kaBP}$ event, a widespread cold event in the $\mathrm{NH}$ (e.g., Alley et al., 1997), is apparent in the stalagmite records (Figs. 5, 10). Stalagmite ANJB-2 $\delta^{18} \mathrm{O}$ and $\delta^{13} \mathrm{C}$ ratios reach their lowest values of -6.8 and $-10.9 \%$, respectively, during that interval, and mineralogy is primary calcite. These proxies suggest a wet interval in NW Madagascar.

The $8.2 \mathrm{ka}$ event was triggered by an abrupt freshwater influx from the melting Laurentide Ice Sheet into the North Atlantic (Alley et al., 1997; Barber et al., 1999; Kleiven et al., 2008; Carlson et al., 2008; Renssen et al., 2010; Wiersma et al., 2011; Wanner et al., 2015). This influx of meltwater altered the density and salinity of the North Atlantic Deep Water (e.g., Thornalley et al., 2009), weakening the Atlantic Meridional overturning circulation (AMOC, e.g., Barber et al., 1999; Clark et al., 2001; Daley et al., 2011; Vellinga and
Wood, 2002; Dong and Sutton, 2002, 2007; Dahl et al., 2005; Zhang and Delworth, 2005; Daley et al., 2011; Renssen et al., 2001). Weakening of the AMOC would cause a widespread cooling in the NH regions (e.g., Clark et al., 2001; Thomas et al., 2007) but warming in the SH regions (Wiersma et al., 2011; Wiersma and Renssen, 2006), creating a "bipolar seesaw" effect (e.g., Crowley, 1992; Broecker, 1998). The interhemispheric temperature difference between the $\mathrm{NH}$ and $\mathrm{SH}$ from this effect may be the driver of the southward displacement of the mean position of the ITCZ during the $8.2 \mathrm{kyr}$ abrupt cooling event. This may have intensified the Malagasy monsoon in NW Madagascar during austral summers, similar to what happened to the South American summer monsoon in Brazil (e.g., Cheng et al., 2009). In contrast, regions in the $\mathrm{NH}$ monsoon regions became drier at $8.2 \mathrm{kaBP}$ as the Asian monsoon and the East Asian monsoon weakened (e.g., Wang et al., 2005; Dykoski et al., 2005; Cheng et al., 2009; Liu et al., 2013). The cold NH climate conditions and the wet climate conditions in NW Madagascar at $8.2 \mathrm{ka} \mathrm{BP}$ (Fig. 10) could suggest causal relationships. However, further research and data will be needed to confirm this possibility.

\section{Conclusions}

Petrography, mineralogy, and stable isotope records from Stalagmite ANJB-2, from Anjohibe Cave, and Stalagmite MAJ-5, from Anjokipoty Cave, combine to suggest three distinct intervals of changing climate in Madagascar during the Holocene: relatively wet conditions during the MEHI, relatively drier conditions, possibly due to episodic dry intervals, during the MMHI, and relatively wet conditions during the MLHI. The timing of stalagmite deposition during the MEHI and the MLHI in NW Madagascar could be attributed to a more southward migration and/or an expanded ITCZ, increasing the duration of the summer rainy seasons, perhaps linked to a stronger Malagasy monsoon. This could have been tied to the temperature gradient between the two hemispheres and weakening of the AMOC. In contrast, the ca. 6500-year depositional hiatus during the MMHI could indicate a northward migration of the ITCZ, leading to relatively drier conditions in NW Madagascar. The evidence of the $8.2 \mathrm{ka}$ event in the Malagasy records may further suggest a close link between paleoenvironmental changes in Madagascar and abrupt climatic events in the $\mathrm{NH}$, suggesting that during the MEHI Madagascar's climate was very sensitive to abrupt ocean-atmosphere events in the $\mathrm{NH}$.

Although the ITCZ is unquestionably one of the climatic drivers influencing climate in Madagascar and the surrounding locations, several climatic factors need to be investigated in more detail. For example, we do not fully understand if the latitudinal migration is paired with the expansion and/or contraction of the ITCZ, which would affect the strengths of the associated monsoon systems. In addition, the interplay between the ITCZ and other factors involving changes in sea 
surface temperatures, particularly IOD-ENSO, needs to be investigated in detail. Data-model comparison (for example at the $8.2 \mathrm{ka}$ event) and improved spatial and temporal resolution of paleoclimate datasets could be an approach to address this challenge.

Data availability. Data for this paper are available at https://www. ncdc.noaa.gov/paleo-search/study/22970 (Voarintsoa et al., 2017c).

\section{The Supplement related to this article is available online} at https://doi.org/10.5194/cp-13-1771-2017-supplement.

\begin{abstract}
Author contributions. NRGV conceived the research and experiments. NRGV, GK, AFMR, and MOMR did the fieldwork and collected the samples. XL, GK, HC, RLE, and NRGV contributed to the ${ }^{230} \mathrm{Th}$ dating analyses. NRGV provided detailed investigation of the two stalagmites, provided stable isotope measurements, prepared thin sections, and conducted X-ray diffraction and SEM analyses on the samples. GK also assisted with the isotopic measurements on Stalagmite ANJB-2. NRGV wrote the first draft of the paper and led the writing. LBR and GAB provided a thorough review of the draft. NRGV and LBR discussed and revised the paper, with additional comments from LW. NRGV revised the paper with input from all authors, reviewers, and editors.
\end{abstract}

Competing interests. The authors declare that they have no conflict of interest.

Special issue statement. This article is part of the special issue "Southern perspectives on climate and the environment from the Last Glacial Maximum through the Holocene: the Southern Hemisphere Assessment of PalaeoEnvironments (SHAPE) project". It is not associated with a conference.

Acknowledgements. This work was supported by grants from (1) the National Natural Science Foundation of China (NSFC 41230524, NBRP 2013CB955902, and NSFC 41472140) to Hai Cheng and Gayatri Kathayat, (2) the Geological Society of America Research Grant (GSA 11166-16) and John Montagne Fund award to Ny Riavo Gilbertinie Voarintsoa, (3) the Miriam Watts-Wheeler Graduate student grant from the Department of Geology at UGA to Ny Riavo Gilbertinie Voarintsoa, and (4) the International Association of Sedimentology postgraduate grant to Ny Riavo Gilbertinie Voarintsoa. We also thank the Schlumberger Foundation for providing additional support to Ny Riavo Gilbertinie Voarintsoa's research. We thank the Department of Geology at the University of Antananarivo, in Madagascar, the Ministry of Energy and Mines, the local village, and guides in Mahajanga for easing our research in Madagascar. We specifically thank Voahangy Ratrimo, former department head of the Department of Geology at the University of Antananarivo, for collaborating with us and for giving us permission to conduct a field expedition in Madagascar. We thank Paul Schroeder for giving us access to use the X-ray diffractometer of the Geology Department to conduct analysis on the mineralogy of the two stalagmites. We thank John Shields of the Georgia Electron Microscopy, University of Georgia, for giving Voarintsoa access to use the Zeiss 1450EP (Zeiss Inc., Thornwood, NY) for SEM purposes. We also thank Sally Walker for allowing us to use the microscope of the paleontology lab and for helping us to photograph the stalagmites at very high resolution. We also thank John Chiang of the University of California at Berkeley for sharing his thoughts and guiding us to literature of relevance to this study.

Edited by: Nerilie Abram

Reviewed by: two anonymous referees

\section{References}

Abram, N. J., Gagan, M. K., Cole, J. E., Hantoro, W. S., and Mudelsee, M.: Recent intensification of tropical climate variability in the Indian Ocean, Nat. Geosci., 1, 849-853, 2008.

Abram, N. J., McGregor, H. V., Gagan, M. K., Hantoro, W. S., and Suwargadi, B. W.: Oscillations in the southern extent of the Indo-Pacific Warm Pool during the mid-Holocene, Quaternary Sci. Rev., 28, 2794-2803, https://doi.org/10.1016/J.Quascirev.2009.07.006, 2009.

Alley, R. B., Mayewski, P. A., Sowers, T., Stuiver, M., Taylor, K. C., and Clark, P. U.: Holocene climatic instability: A prominent, widespread event 8200 yr ago, Geology, 25, 483-486, 1997.

Asrat, A., Baker, A., Mohammed, M. U., Leng, M. J., Van Calsteren, P., and Smith, C.: A high-resolution multi-proxy stalagmite record from Mechara, Southeastern Ethiopia: palaeohydrological implications for speleothem palaeoclimate reconstruction, J. Quaternary Sci., 22, 53-63, https://doi.org/10.1002/Jqs.1013, 2007.

Barber, D. C., Dyke, A., Hillaire-Marcel, C., Jennings, A. E., Andrews, J. T., Kerwin, M. W., Bilodeau, G., McNeely, R., Southon, J., Morehead, M. D., and Gagnon, J. M.: Forcing of the cold event of 8,200 years ago by catastrophic drainage of Laurentide lakes, Nature, 400, 344-348, https://doi.org/10.1038/22504, 1999.

Bard, E., Rostek, F., and Sonzogni, C.: Interhemispheric synchrony of the last deglaciation inferred from alkenone palaeothermometry, Nature, 385, 707-710, https://doi.org/10.1038/385707a0, 1997.

Beal, L. M., De Ruijter, W. P. M., Biastoch, A., Zahn, R., and SCOR/WCRP/IAPSO Working Group 136: On the role of the Agulhas system in ocean circulation and climate, Nature, 472, 429-436, https://doi.org/10.1038/Nature09983, 2011.

Bosák, P.: Dating of processes in karst and caves: implication for show caves presentation, 6th ISCA Congress Proceedings, Slovakia, 2011, 34-41, 2011.

Braconnot, P., Otto-Bliesner, B., Harrison, S., Joussaume, S., Peterchmitt, J.-Y., Abe-Ouchi, A., Crucifix, M., Driesschaert, E., Fichefet, Th., Hewitt, C. D., Kageyama, M., Kitoh, A., Laîné, A., Loutre, M.-F., Marti, O., Merkel, U., Ramstein, G., Valdes, P., Weber, S. L., Yu, Y., and Zhao, Y.: Results of PMIP2 coupled simulations of the Mid-Holocene and Last Glacial Maximum Part 1: experiments and large-scale features, Clim. Past, 3, 261277, https://doi.org/10.5194/cp-3-261-2007, 2007. 
Broccoli, A. J., Dahl, K. A., and Stouffer, R. J.: Response of the ITCZ to Northern Hemisphere cooling, Geophys. Res. Lett., 33, L01702, https://doi.org/10.1029/2005g1024546, 2006.

Broecker, W. S.: Paleocean circulation during the Last Deglaciation: A bipolar seesaw?, Paleoceanography, 13, 119-121, https://doi.org/10.1029/97PA03707, 1998.

Brook, G. A., Rafter, M. A., Railsback, L. B., Sheen, S. W., and Lundberg, J.: A high-resolution proxy record of rainfall and ENSO since AD 1550 from layering in stalagmites from Anjohibe Cave, Madagascar, The Holocene, 9, 695-705, https://doi.org/10.1191/095968399677907790, 1999.

Brown, J., Lynch, A. H., and Marshall, A. G.: Variability of the Indian Ocean Dipole in coupled model paleoclimate simulations, J. Geophys. Res.-Atmos., 114, D11105, https://doi.org/10.1029/2008jd010346, 2009.

Burney, D. A., James, H. F., Grady, F. V., Rafamantanantsoa, J. G., Ramilisonina, Wright, H. T., and Cowart, J. B.: Environmental change, extinction and human activity: evidence from caves in NW Madagascar, J. Biogeogr., 24, 755-767, https://doi.org/10.1046/J.1365-2699.1997.00146.X, 1997.

Burney, D. A., Burney, L. P., Godfrey, L. R., Jungers, W. L., Goodman, S. M., Wright, H. T., and Jull, A. J. T.: A chronology for late prehistoric Madagascar, J. Hum. Evol., 47, 25-63, https://doi.org/10.1016/J.Jhevol.2004.05.005, 2004.

Burns, S. J., Godfrey, L. R., Faina, P., McGee, D., Hardt, B., Ranivoharimanana, L., and Randrianasy, J.: Rapid human-induced landscape transformation in Madagascar at the end of the first millennium of the Common Era, Quaternary Sci. Rev., 134, 92-99, https://doi.org/10.1016/j.quascirev.2016.01.007, 2016.

Cabrol, P. and Coudray, J.: Climatic fluctuations influence the genesis and diagenesis of carbonate speleothems in southwestern France, National Speleological Society Bulletin 44, 112-117, 1982.

Carlson, A. E., Legrande, A. N., Oppo, D. W., Came, R. E., Schmidt, G. A., Anslow, F. S., Licciardi, J. M., and Obbink, E. A.: Rapid early Holocene deglaciation of the Laurentide ice sheet, Nat. Geosci., 1, 620-624, https://doi.org/10.1038/ngeo285, 2008.

Cheng, H., Fleitmann, D., Edwards, R. L., Wang, X. F., Cruz, F. W., Auler, A. S., Mangini, A., Wang, Y. J., Kong, X. G., Burns, S. J., and Matter, A.: Timing and structure of the $8.2 \mathrm{kyr} \mathrm{BP}$ event inferred from $\delta^{18} \mathrm{O}$ records of stalagmites from China, Oman, and Brazil, Geology, 37, 1007-1010, https://doi.org/10.1130/G30126a.1, 2009.

Cheng, H., Edwards, R. L., Shen, C. C., Polyak, V. J., Asmerom, Y., Woodhead, J., Hellstrom, J., Wang, Y. J., Kong, X. G., Spotl, C., Wang, X. F., and Alexander, E. C.: Improvements in Th-230 dating, Th-230 and U-234 half-life values, and U-Th isotopic measurements by multi-collector inductively coupled plasma mass spectrometry, Earth Planet. Sc. Lett., 371, 82-91, https://doi.org/10.1016/J.Epsl.2013.04.006, 2013.

Chiang, J. C. H. and Bitz, C. M.: Influence of high latitude ice cover on the marine Intertropical Convergence Zone, Clim. Dynam., 25, 477-496, https://doi.org/10.1007/s00382-005-0040-5, 2005.

Chiang, J. C. H. and Friedman, A. R.: Extratropical Cooling, Interhemispheric Thermal Gradients, and Tropical Climate Change, Annu. Rev. Earth Pl. Sc., 40, 383-412, https://doi.org/10.1146/Annurev-Earth-042711-105545, 2012.
Clark, P. U., Marshall, S. J., Clarke, G. K. C., Hostetler, S. W., Licciardi, J. M., and Teller, J. T.: Freshwater Forcing of Abrupt Climate Change During the Last Glaciation, Science, 293, 283-287, https://doi.org/10.1126/science.1062517, 2001.

Crowley, B. E.: A refined chronology of prehistoric Madagascar and the demise of the megafauna, Quaternary Sci. Rev., 29, 25912603, https://doi.org/10.1016/J.Quascirev.2010.06.030, 2010.

Crowley, B. E. and Samonds, K. E.: Stable carbon isotope values confirm a recent increase in grasslands in northwestern Madagascar, The Holocene, 23, 1066-1073, https://doi.org/10.1177/0959683613484675, 2013.

Crowley, T. J.: North Atlantic Deep Water cools the southern hemisphere, Paleoceanography, 7, 489-497, https://doi.org/10.1029/92PA01058, 1992.

Crowther, A., Lucas, L., Helm, R., Horton, M., Shipton, C., Wright, H. T., Walshaw, S., Pawlowicz, M., Radimilahy, C., Douka, K., Picornell-Gelabert, L., Fuller, D. Q., and Boivin, N. L.: Ancient crops provide first archaeological signature of the westward Austronesian expansion, P. Natl. Acad. Sci. USA, 113, 6635-6640, https://doi.org/10.1073/pnas.1522714113, 2016.

Cruz, F. W., Burns, S. J., Karmann, I., Sharp, W. D., Vuille, M., Cardoso, A. O., Ferrari, J. A., Dias, P. L. S., and Viana, O.: Insolation-driven changes in atmospheric circulation over the past 116,000 years in subtropical Brazil, Nature, 434, 63-66, https://doi.org/10.1038/Nature03365, 2005.

Dahl, K., Broccoli, A., and Stouffer, R.: Assessing the role of North Atlantic freshwater forcing in millennial scale climate variability: a tropical Atlantic perspective, Clim. Dynam., 24, 325-346, https://doi.org/10.1007/s00382-004-0499-5, 2005.

Daley, T. J., Thomas, E. R., Holmes, J. A., Street-Perrott, F. A., Chapman, M. R., Tindall, J. C., Valdes, P. J., Loader, N. J., Marshall, J. D., Wolff, E. W., Hopley, P. J., Atkinson, T., Barber, K. E., Fisher, E. H., Robertson, I., Hughes, P. D. M., and Roberts, C. N.: The $8200 \mathrm{yr}$ BP cold event in stable isotope records from the North Atlantic region, Global Planet. Change, 79, 288-302, https://doi.org/10.1016/j.gloplacha.2011.03.006, 2011.

Dewar, R. E. and Richard, A. F.: Evolution in the hypervariable environment of Madagascar, P. Natl. Acad. Sci. USA, 104, 1372313727, https://doi.org/10.1073/pnas.0704346104, 2007.

DGM (Direction Générale de la Météorologie): Le changement climatique à Madagascar, http://web.csag.uct.ac.za/ mtadross/ Madagascarglossy.pdf (last access: 29 November 2017), 2008.

Dong, B. W. and Sutton, R. T.: Adjustment of the coupled oceanatmosphere system to a sudden change in the Thermohaline Circulation, Geophys. Res. Lett., 29, 1728, 2002.

Dong, B. and Sutton, R. T.: Enhancement of ENSO variability by a weakened Atlantic thermohaline circulation in a coupled GCM, J. Climate, 20, 4920-4939, https://doi.org/10.1175/Jcli4284.1, 2007.

Dorale, J. A., Edwards, R. L., Alexander, E. C., Shen, C.-C., Richards, D. A., and Cheng, H.: Uranium-Series Dating of Speleothems: Current Techniques, Limits, \& Applications, in: Studies of Cave Sediments: Physical and Chemical Records of Paleoclimate, edited by: Sasowsky, I. D. and Mylroie, J., Springer US, Boston, MA, 177-197, 2004.

Douglass, K. and Zinke, J.: Forging Ahead By Land and By Sea: Archaeology and Paleoclimate Reconstruction in Madagascar, Afr. Archaeol. Rev., 32, 267-299, https://doi.org/10.1007/s10437015-9188-5, 2015. 
Dutton, A., Bard, E., Antonioli, F., Esat, T. M., Lambeck, K., and McCulloch, M. T.: Phasing and amplitude of sea-level and climate change during the penultimate interglacial, Nat. Geosci., 2, 355-359, https://doi.org/10.1038/Ngeo470, 2009.

Dykoski, C. A., Edwards, R. L., Cheng, H., Yuan, D. X., Cai, Y. J., Zhang, M. L., Lin, Y. S., Qing, J. M., An, Z. S., and Revenaugh, J.: A high-resolution, absolute-dated Holocene and deglacial Asian monsoon record from Dongge Cave, China, Earth Planet. Sc. Lett., 233, 71-86, https://doi.org/10.1016/j.epsl.2005.01.036, 2005.

Edwards, R. L., Chen, J. H., and Wasserburg, G. J.: U-238 U234-Th-230-Th-232 Systematics and the Precise Measurement of Time over the Past 500000 Years, Earth Planet. Sc. Lett., 81, 175-192, 1987.

Fairchild, I. J. and Baker, A.: Speleothem Science: From Processes to Past Environments, edited by: Bradley, R., Wiley-Blackwell, 2012.

Fairchild, I. J. and McMillan, E. A.: Speleothems as indicators of wet and dry periods, Int. J. Speleol., 36, 69-74, 2007.

Fairchild, I. J., Borsato, A., Tooth, A. F., Frisia, S., Hawkesworth, C. J., Huang, Y. M., McDermott, F., and Spiro, B.: Controls on trace element ( $\mathrm{Sr}-\mathrm{Mg}$ ) compositions of carbonate cave waters: implications for speleothem climatic records, Chem. Geol., 166, 255269, https://doi.org/10.1016/S0009-2541(99)00216-8, 2000.

Fleitmann, D., Burns, S. J., Mudelsee, M., Neff, U., Kramers, J., Mangini, A., and Matter, A.: Holocene forcing of the Indian monsoon recorded in a stalagmite from Southern Oman, Science, 300, 1737-1739, https://doi.org/10.1126/Science.1083130, 2003.

Fleitmann, D., Burns, S. J., Mangini, A., Mudelsee, M., Kramers, J., Villa, I., Neff, U., Al-Subbary, A. A., Buettner, A., Hippler, D., and Matter, A.: Holocene ITCZ and Indian monsoon dynamics recorded in stalagmites from Oman and Yemen (Socotra), Quaternary Sci. Rev., 26, 170-188, https://doi.org/10.1016/J.Quascirev.2006.04.012, 2007.

Frierson, D. M. W. and Hwang, Y. T.: Extratropical Influence on ITCZ Shifts in Slab Ocean Simulations of Global Warming, J. Climate, 25, 720-733, https://doi.org/10.1175/Jcli-D-11$00116.1,2012$.

Frisia, S., Borsato, A., Fairchild, I. J., McDermott, F., and Selmo, E. M.: Aragonite-calcite relationships in speleothems (Grotte de Clamouse, France): environment, fabrics, and carbonate geochemistry, J. Sediment. Res., 772, 687-699, 2002.

Garcin, Y., Vincens, A., Williamson, D., Guiot, J., and Buchet, G.: Wet phases in tropical southern Africa during the last glacial period, Geophys. Res. Lett., 33, L07703, https://doi.org/10.1029/2005GL025531, 2006.

Gasse, F.: Hydrological changes in the African tropics since the Last Glacial Maximum, Quaternary Sci. Rev., 19, 189-211, https://doi.org/10.1016/S0277-3791(99)00061-X, 2000.

Gasse, F. and Van Campo, E.: A 40,000-yr pollen and diatom record from Lake Tritrivakely, Madagascar, in the southern tropics, Quaternary Res., 49, 299-311, https://doi.org/10.1006/Qres.1998.1967, 1998.

Gommery, D., Ramanivosoa, B., Faure, M., Guerin, C., Kerloc'h, P., Senegas, F., and Randrianantenaina, H.: Oldest evidence of human activities in Madagascar on subfossil hippopotamus bones from Anjohibe (Mahajanga Province), C. R. Palevol. , 10, 271278, https://doi.org/10.1016/j.crpv.2011.01.006, 2011.
Haug, G. H., Hughen, K. A., Sigman, D. M., Peterson, L. C., and Rohl, U.: Southward migration of the intertropical convergence zone through the Holocene, Science, 293, 1304-1308, https://doi.org/10.1126/Science.1059725, 2001.

Head, M. J. and Gibbard, P. L.: Formal subdivision of the Quaternary System/Period: Past, present, and future, Quaternary Int., 383, 4-35, https://doi.org/10.1016/j.quaint.2015.06.039, 2015.

Holmgren, K., Karlen, W., and Shaw, P. A.: Paleoclimatic Significance of the Stable Isotopic Composition and Petrology of a Late Pleistocene Stalagmite from Botswana, Quaternary Res., 43, 320-328, https://doi.org/10.1006/qres.1995.1038, 1995.

Holmgren, K., Lee-Thorp, J. A., Cooper, G. R. J., Lundblad, K., Partridge, T. C., Scott, L., Sithaldeen, R., Talma, A. S., and Tyson, P. D.: Persistent millennial-scale climatic variability over the past 25,000 years in Southern Africa, Quaternary Sci. Rev., 22, 23112326, https://doi.org/10.1016/S0277-3791(03)00204-X, 2003.

Johnson, K. R., Hu, C. Y., Belshaw, N. S., and Henderson, G. M.: Seasonal trace-element and stable-isotope variations in a Chinese speleothem: The potential for high-resolution paleomonsoon reconstruction, Earth Planet. Sc. Lett., 244, 394-407, https://doi.org/10.1016/j.epsl.2006.01.064, 2006.

Jungers, W. L., Demes, B., and Godfrey, L. R.: How big were the "Giant" extinct lemurs of Madagascar?, in: Elwyn Simons: A search for origins, edited by: Fleagle, J. G. and Gilbert, C. G., Springer, New York, 343-360, 2008.

Jury, M. R.: The Climate of Madagascar, in: The Natural History of Madagascar, edited by: Goodman, S. M. and Benstead, J. P., Chicago, Universtity of Chicago, 75-87, 2003.

Kang, S. M., Held, I. M., Frierson, D. M. W., and Zhao, M.: The response of the ITCZ to extratropical thermal forcing: Idealized slab-ocean experiments with a GCM, J. Climate, 21, 3521-3532, https://doi.org/10.1175/2007jcli2146.1, 2008.

Karmann, I., Cruz, F. W., Viana, O., and Burns, S. J.: Climate influence on geochemistry parameters of waters from Santana-Perolas cave system, Brazil, Chem. Geol., 244, 232247, https://doi.org/10.1016/j.chemgeo.2007.06.029, 2007.

Kim, S.-T. and O'Neil, J. R.: Equilibrium and nonequilibrium oxygen isotope effects in synthetic carbonates, Geochim. Cosmochim. Ac., 61, 3461-3475, https://doi.org/10.1016/S00167037(97)00169-5, 1997.

Kim, S. T., O'Neil, J. R., Hillaire-Marcel, C., and Mucci, A.: Oxygen isotope fractionation between synthetic aragonite and water: Influence of temperature and $\mathrm{Mg} 2+$ concentration, Geochim. Cosmochim. Ac., 71, 4704-4715, https://doi.org/10.1016/J.Gca.2007.04.019, 2007.

Kleiven, H. F., Kissel, C., Laj, C., Ninnemann, U. S., Richter, T. O., and Cortijo, E.: Reduced North Atlantic Deep Water coeval with the glacial Lake Agassiz freshwater outburst, Science, 319, 60-64, https://doi.org/10.1126/science.1148924, 2008.

Konecky, B. L., Russell, J. M., Johnson, T. C., Brown, E. T., Berke, M. A., Werne, J. P., and Huang, Y. S.: Atmospheric circulation patterns during late Pleistocene climate changes at Lake Malawi, Africa, Earth Planet. Sc. Lett., 312, 318-326, https://doi.org/10.1016/j.epsl.2011.10.020, 2011.

Kuhnert, H., Kuhlmann, H., Mohtadi, M., Meggers, H., Baumann, K. H., and Patzold, J.: Holocene tropical western Indian Ocean sea surface temperatures in covariation with climatic changes in the Indonesian region, Paleoceanography, 29, 423437, https://doi.org/10.1002/2013pa002555, 2014. 
Kutzbach, J. E. and Liu, Z.: Response of the African Monsoon to Orbital Forcing and Ocean Feedbacks in the Middle Holocene, Science, 278, 440-443, 1997.

Lachniet, M. S., Bernal, J. P., Asmerom, Y., and Polyak, V.: Uranium loss and aragonite-calcite age discordance in a calcitized aragonite stalagmite, Quat. Geochronol., 14, 26-37, https://doi.org/10.1016/j.quageo.2012.08.003, 2012.

Lambert, W. J. and Aharon, P.: Controls on dissolved inorganic carbon and delta $\mathrm{C}-13$ in cave waters from DeSoto Caverns: Implications for speleothem delta C-13 assessments, Geochim. Cosmochim. Ac., 75, 753-768, https://doi.org/10.1016/j.gca.2010.11.006, 2011.

Lee, T. and McPhaden, M. J.: Decadal phase change in largescale sea level and winds in the Indo-Pacific region at the end of the 20th century, Geophys. Res. Lett., 35, L01605, https://doi.org/10.1029/2007gl032419, 2008.

Li, T., Wang, B., Chang, C. P., and Zhang, Y. S.: A theory for the Indian Ocean dipole-zonal mode, J. Atmos. Sci., 60, 2119-2135, https://doi.org/10.1175/15200469(2003)060<2119:Atftio>2.0.Co;2, 2003.

Liang, F., Brook, G. A., Kotlia, B. S., Railsback, L. B., Hardt, B., Cheng, H., Edwards, R. L., and Kandasamy, S.: Panigarh cave stalagmite evidence of climate change in the Indian Central Himalaya since AD 1256: Monsoon breaks and winter southern jet depressions, Quaternary Sci. Rev., 124, 145-161, 2015.

Liu, Z., Kutzbach, J., and Wu, L.: Modeling climate shift of El Nino variability in the Holocene, Geophys. Res. Lett., 27, 2265-2268, https://doi.org/10.1029/2000GL011452, 2000.

Liu, Y. H., Henderson, G. M., Hu, C. Y., Mason, A. J., Charnley, N., Johnson, K. R., and Xie, S. C.: Links between the East Asian monsoon and North Atlantic climate during the 8,200 year event, Nat. Geosci., 6, 117-120, https://doi.org/10.1038/Ngeo1708, 2013.

Lutjeharms, J. R. E.: The Aghulas Current, 330 pp., ISBN: 103540423923, Springer, 2006.

MacPhee, R. D. E. and Burney, D. A.: Dating of Modified Femora of Extinct Dwarf Hippopotamus from Southern Madagascar - Implications for Constraining Human Colonization and Vertebrate Extinction Events, J. Archaeol. Sci., 18, 695-706, https://doi.org/10.1016/0305-4403(91)90030-S, 1991.

Marcott, S. A., Shakun, J. D., Clark, P. U., and Mix, A. C.: A Reconstruction of Regional and Global Temperature for the Past 11,300 Years, Science, 339, 1198, https://doi.org/10.1126/science.1228026, 2013.

Matsumoto, K. and Burney, D. A.: Late Holocene environments at Lake Mitsinjo, northwestern Madagascar, The Holocene, 4, 1624, 1994.

Mayewski, P. A., Rohling, E. E., Stager, J. C., Karlen, W., Maasch, K. A., Meeker, L. D., Meyerson, E. A., Gasse, F., van Kreveld, S., Holmgren, K., Lee-Thorp, J., Rosqvist, G., Rack, F., Staubwasser, M., Schneider, R. R., and Steig, E. J.: Holocene climate variability, Quaternary Res., 62, 243-255, https://doi.org/10.1016/J.Yqres.2004.07.001, 2004.

McDonald, J., Drysdale, R., Hill, D., Chisari, R., and Wong, H.: The hydrochemical response of cave drip waters to sub-annual and inter-annual climate variability, Wombeyan Caves, SE Australia, Chem. Geol., 244, 605-623, 2007.

McGee, D., Donohoe, A., Marshall, J., and Ferreira, D.: Changes in ITCZ location and cross-equatorial heat trans- port at the Last Glacial Maximum, Heinrich Stadial 1, and the mid-Holocene, Earth Planet. Sc. Lett., 390, 69-79, https://doi.org/10.1016/J.Epsl.2013.12.043, 2014.

McMillan, E. A., Fairchild, I. J., Frisia, S., Borsato, A., and McDermott, F.: Annual trace element cycles in calcite-aragonite speleothems: evidence of drought in the western Mediterranean 1200-1100 yr BP, J. Quaternary Sci., 20, 423-433, https://doi.org/10.1002/jqs.943, 2005.

Meyers, G., McIntosh, P., Pigot, L., and Pook, M.: The Years of El Niño, La Niña, and Interactions with the Tropical Indian Ocean, J. Climate, 20, 2872-2880, https://doi.org/10.1175/JCLI4152.1, 2007.

Middleton, J. and Middleton, V.: Karst and caves of Madagascar, Cave and Karst Science, 29, 13-20, 2002.

Murray, J. W.: The deposition of calcite and aragonite in caves, J. Geol., 62, 481-492, 1954.

Nassor, A. and Jury, M. R.: Intra-seasonal climate variability of Madagascar. Part 1: Mean summer conditions, Meteorol. Atmos. Phys., 65, 31-41, https://doi.org/10.1007/Bf01030267, 1998.

Nicholson, S. E.: Environmental change within the historical period, in: The Physical Geography of Africa, edited by: Goudie, A. S., Adams, W. M., and Orme, A., Oxford University Press, Oxford, 60-75, 1996.

Niggemann, S., Mangini, A., Mudelsee, M., Richter, D. K., and Wurth, G.: Sub-Milankovitch climatic cycles in Holocene stalagmites from Sauerland, Germany, Earth Planet. Sc. Lett., 216, 539-547, https://doi.org/10.1016/S0012-821x(03)00513-2, 2003.

Partridge, T. C., Demenocal, P. B., Lorentz, S. A., Paiker, M. J., and Vogel, J. C.: Orbital forcing of climate over South Africa: A 200,000-year rainfall record from the Pretoria saltpan, Quaternary Sci. Rev., 16, 1125-1133, 1997.

Paul, D. and Skrzypek, G.: Assessment of carbonate-phosphoric acid analytical technique performed using GasBench II in continuous flow isotope ratio mass spectrometry, Int. J. Mass Spectrom., 262, 180-186, https://doi.org/10.1016/j.ijms.2006.11.006, 2007.

Perrin, C., Prestimonaco, L., Servelle, G., Tilhac, R., Maury, M., and Cabrol, P.: Aragonite-calcite speleothems: identifying original and diagenetic features, J. Sediment. Res., 84, 245-269, 2014.

Pobeguin, T.: Sur les concrétions calcaires observés dans la Grotte de Moulis (Ariège), Société Géologique de la France, Compte Rendus, 241, 1791-1793, 1965.

Railsback, L. B.: Atlas of speleothem microfabrics, available at: www.gly.uga.edu/railsback/speleoatlas/SAindex1.html, 2000.

Railsback, L. B., Brook, G. A., Chen, J., Kalin, R., and Fleisher, C. J.: Environmental Controls on the Petrology of a Late Holocene Speleothem from Botswana with annual layers of aragonite and calcite, J. Sediment. Res. A, 64, 147-155, 1994.

Railsback, L. B., Akers, P. D., Wang, L. X., Holdridge, G. A., and Voarintsoa, N. R.: Layer-bounding surfaces in stalagmites as keys to better paleoclimatological histories and chronologies, Int. J. Speleol., 42, 167-180, https://doi.org/10.5038/1827806x.42.3.1, 2013.

Railsback, L. B., Xiao, H. L., Liang, F. Y., Akers, P. D., Brook, G. A., Dennis, W. M., Lanier, T. E., Tan, M., Cheng, H., and Edwards, R. L.: A stalagmite record of abrupt climate change and possible Westerlies-derived atmo- 
spheric precipitation during the Penultimate Glacial Maximum in northern China, Palaeogeogr. Palaeocl., 393, 30-44, https://doi.org/10.1016/J.Palaeo.2013.10.013, 2014.

Railsback, L. B., Brook, G. A., Ellwood, B. B., Liang, F., Cheng, H., and Edwards, R. L.: A record of wet glacial stages and dry interglacial stages over the last $560 \mathrm{kyr}$ from a standing massive stalagmite in Carlsbad Cavern, New Mexico, USA, Palaeogeogr. Palaeocl., 438, 256-266, https://doi.org/10.1016/j.palaeo.2015.08.010, 2015.

Railsback, L. B., Brook, G. A., Liang, F., Marais, E., Cheng, H., and Edwards, R. L.: A multi-proxy stalagmite record from northwestern Namibia of regional drying with increasing global-scale warmth over the last $47 \mathrm{kyr}$ : The interplay of a globally shifting ITCZ with regional currents, winds, and rainfall, Palaeogeogr. Palaeocl., 461, 109-121, 2016.

Renssen, H., Goosse, H., Fichefet, T., and Campin, J. M.: The $8.2 \mathrm{kyr}$ BP event simulated by a Global AtmosphereSea-Ice-Ocean Model, Geophys. Res. Lett., 28, 1567-1570, https://doi.org/10.1029/2000GL012602, 2001.

Renssen, H., Goosse, H., Crosta, X., and Roche, D. M.: Early Holocene Laurentide Ice Sheet deglaciation causes cooling in the high-latitude Southern Hemisphere through oceanic teleconnection, Paleoceanography, 25, PA3204, https://doi.org/10.1029/2009pa001854, 2010.

Romanek, C. S., Grossman, E. L., and Morse, J. W.: Carbon Isotopic Fractionation in Synthetic Aragonite and Calcite - Effects of Temperature and Precipitation Rate, Geochim. Cosmochim. Ac., 56, 419-430, https://doi.org/10.1016/0016-7037(92)901426, 1992.

Rubinson, M. and Clayton, R. N.: Carbon-13 fractionation between aragonite and calcite, Geochim. Cosmochim. Ac., 33, 997-1002, 1969.

Sachs, J. P., Sachse, D., Smittenberg, R. H., Zhang, Z. H., Battisti, D. S., and Golubic, S.: Southward movement of the Pacific intertropical convergence zone AD 1400-1850, Nat. Geosci., 2, 519-525, https://doi.org/10.1038/ngeo554, 2009.

Saint-Ours, J. D.: Les phénomènes karstiques à Madagascar, Annales de Spéléologie, 14, 275-291, 1959.

Saji, N. H. and Yamagata, T.: Possible impacts of Indian Ocean Dipole mode events on global climate, Clim. Res., 25, 151-169, https://doi.org/10.3354/Cr025151, 2003.

Saji, N. H., Goswami, B. N., Vinayachandran, P. N., and Yamagata, T.: A dipole mode in the tropical Indian Ocean, Nature, 401, 360363, https://doi.org/10.1038/43855, 1999.

Schefuß, E., Schouten, S., and Schneider, R. R.: Climatic controls on central African hydrology during the past 20,000 years, Nature, 437, 1003-1006, 2005.

Schefuß, E., Kuhlmann, H., Mollenhauer, G., Prange, M., and Patzold, J.: Forcing of wet phases in southeast Africa over the past 17,000 years, Nature, 480, 509-512, https://doi.org/10.1038/nature10685, 2011.

Schneider, T., Bischoff, T., and Haug, G. H.: Migrations and dynamics of the intertropical convergence zone, Nature, 513, 4553, https://doi.org/10.1038/Nature13636, 2014.

Scholz, D. and Hoffmann, D. L.: StalAge -An algorithm designed for construction of speleothem age models, Quat. Geochronol., 6, 369-382, https://doi.org/10.1016/j.quageo.2011.02.002, 2011.

Scholz, D., Hoffmann, D. L., Hellstrom, J., and Ramsey, C. B.: A comparison of different methods for speleothem age modelling, Quat. Geochronol., 14, 94-104, https://doi.org/10.1016/j.quageo.2012.03.015, 2012.

Schott, F. A., Xie, S. P., and McCreary, J. P.: Indian Ocean Circulation and Climate Variability, Rev. Geophys., 47, RG1002, https://doi.org/10.1029/2007rg000245, 2009.

Scroxton, N., Burns, S. J., McGee, D., Hardt, B., Godfrey, L. R., Ranivoharimanana, L., and Faina, P.: Hemispherically in-phase precipitation variability over the last 1700 years in a Madagascar speleothem record, Quaternary Sci. Rev., 164, 25-36, https://doi.org/10.1016/j.quascirev.2017.03.017, 2017.

Seltzer, G., Rodbell, D., and Burns, S. J.: Isotopic evidence for Late Glacial and Holocene hydrologic change in tropical South America, Geology, 28, 35-38, 2000.

Shen, C.-C., Lawrence Edwards, R., Cheng, H., Dorale, J. A., Thomas, R. B., Bradley Moran, S., Weinstein, S. E., and Edmonds, H. N.: Uranium and thorium isotopic and concentration measurements by magnetic sector inductively coupled plasma mass spectrometry, Chem. Geol., 185, 165-178, 2002.

Shinoda, T., Alexander, M. A., and Hendon, H. H.: Remote Response of the Indian Ocean to Interannual SST Variations in the Tropical Pacific, J. Climate, $\quad 17, \quad 362-372, \quad$ https://doi.org/10.1175/15200442(2004)017<0362:RROTIO>2.0.CO;2, 2004.

Shtober-Zisu, N., Schwarcz, H. P., Konyer, N., Chow, T., and Noseworthy, M. D.: Macroholes in stalagmites and the search for lost water, J. Geophys. Res.-Earth, 117, F03020, https://doi.org/10.1029/2011jf002288, 2012.

Siegel, F. R.: Aspects of calcium carbonate deposition in Great Onyx Cave, Kentucky, Sedimentology, 4, 285-299, 1965.

Singarayer, J. S. and Burrough, S. L.: Interhemispheric dynamics of the African rainbelt during the late Quaternary, Quaternary Sci. Rev., 124, 48-67, 2015.

Skrzypek, G. and Paul, D.: Delta C-13 analyses of calcium carbonate: comparison between the GasBench and elemental analyzer techniques, Rapid Commun. Mass Sp., 20, 2915-2920, https://doi.org/10.1002/rcm.2688, 2006.

Sletten, H. R., Railsback, L. B., Liang, F. Y., Brook, G. A., Marais, E., Hardt, B. F., Cheng, H., and Edwards, R. L.: A petrographic and geochemical record of climate change over the last 4600 years from a northern Namibia stalagmite, with evidence of abruptly wetter climate at the beginning of southern Africa's Iron Age, Palaeogeogr. Palaeocl., 376, 149-162, https://doi.org/10.1016/J.Palaeo.2013.02.030, 2013.

Sonzogni, C., Bard, E., and Rostek, F.: Tropical sea-surface temperatures during the last glacial period: a view based on alkenones in Indian Ocean sediments, Quaternary Sci. Rev., 17, 1185-1201, https://doi.org/10.1016/S0277-3791(97)00099-1, 1998.

Suzuki, T.: Seasonal variation of the ITCZ and its characteristics over central Africa, Theor. Appl. Climatol., 103, 39-60, https://doi.org/10.1007/s00704-010-0276-9, 2011.

Talento, S. and Barreiro, M.: Simulated sensitivity of the tropical climate to extratropical thermal forcing: tropical SSTs and African land surface, Clim. Dynam., 47, 1091-1110, https://doi.org/10.1007/s00382-015-2890-9, 2016.

Tarutani, T., Clayton, R. N., and Mayeda, T. K.: The effect of polymorphism and magnesium substitution on oxygen isotope fractionation between calcium carbonate and water, Geochim. Cosmochim. Ac., 33, 987-996, https://doi.org/10.1016/00167037(69)90108-2, 1969. 
Thomas, D. S. G., Bailey, R., Shaw, P. A., Durcan, J. A., and Singarayer, J. S.: Late Quaternary highstands at Lake Chilwa, Malawi: Frequency, timing and possible forcing mechanisms in the last 44 ka, Quaternary Sci. Rev., 28, 526-539, 2009.

Thomas, E. R., Wolff, E. W., Mulvaney, R., Steffensen, J. P., Johnsen, S. J., Arrowsmith, C., White, J. W. C., Vaughn, B., and Popp, T.: The $8.2 \mathrm{ka}$ event from Greenland ice cores, Quaternary Sci. Rev., 26, 70-81, https://doi.org/10.1016/j.quascirev.2006.07.017, 2007.

Thornalley, D. J. R., Elderfield, H., and McCave, I. N.: Holocene oscillations in temperature and salinity of the surface subpolar North Atlantic, Nature, 457, 711-714, https://doi.org/10.1038/nature07717, 2009.

Thrailkill, J.: Carbonate Deposition in Carlsbad Caverns, J. Geol., 79, 683-695, 1971.

Tierney, J. E., Russell, J. M., Huang, Y., Damsté, J. S. S., Hopmans, E. C., and Cohen, A. S.: Northern Hemisphere Controls on Tropical Southeast African Climate During the Past 60,000 Years, Science, 322, 252-255, 2008.

Tierney, J. E., Russell, J. M., and Huang, Y.: A molecular perspective on Late Quaternary climate and vegetation change in the Lake Tanganyika basin, East Africa, Quaternary Sci. Rev., 29, 787-800, https://doi.org/10.1016/j.quascirev.2009.11.030, 2010.

Tierney, J. E., Smerdon, J. E., Anchukaitis, K. J., and Seager, R.: Multidecadal variability in East African hydroclimate controlled by the Indian Ocean, Nature, 493, 389-392, 2013.

Truc, L., Chevalier, M., Favier, C., Cheddadi, R., Meadows, M. E., Scott, L., Carr, A. S., Smith, G. F., and Chase, B. M.: Quantification of climate change for the last 20,000 years from Wonderkrater, South Africa: Implications for the long-term dynamics of the Intertropical Convergence Zone, Palaeogeogr. Palaeocl., 386, 575-587, 2013.

Vasey, N., Burney, D. A., and Godfrey, L.: Coprolites associated with Archaeolemur remains in North-western Madagascar suggest dietary diversity and cave use in a subfossil prosimian, in: Leaping Ahead: Advances in Prosimian Biology, edited by: Masters, J., Gamba, M., and Génin, F., Springer, New York, NY, 149156, 2013.

Vellinga, M. and Wood, R. A.: Global climatic impacts of a collapse of the Atlantic thermohaline circulation, Climatic Change, 54, 251-267, https://doi.org/10.1023/A:1016168827653, 2002.

Venzke, S., Latif, M., and Villwock, A.: The Coupled GCM ECHO2, J. Climate, 13, 1371-1383, https://doi.org/10.1175/15200442(2000)013<1371:TCGE>2.0.CO;2, 2000.

Verschuren, D., Sinninghe Damste, J. S., Moernaut, J., Kristen, I., Blaauw, M., Fagot, M., and Haug, G. H.: Half-precessional dynamics of monsoon rainfall near the East African Equator, Nature, 462, 637-641, 2009.

Vinther, B. M., Buchardt, S. L., Clausen, H. B., Dahl-Jensen, D., Johnsen, S. J., Fisher, D. A., Koerner, R. M., Raynaud, D., Lipenkov, V., Andersen, K. K., Blunier, T., Rasmussen, S. O., Steffensen, J. P., and Svensson, A. M.: Holocene thinning of the Greenland ice sheet, Nature, 461, 385-388, https://doi.org/10.1038/nature08355, 2009.

Virah-Sawmy, M., Willis, K. J., and Gillson, L.: Threshold response of Madagascar's littoral forest to sea-level rise, Global Ecol. Biogeogr., 18, 98-110, https://doi.org/10.1111/j.14668238.2008.00429.x, 2009.
Virah-Sawmy, M., Willis, K. J., and Gillson, L.: Evidence for drought and forest declines during the recent megafaunal extinctions in Madagascar, J. Biogeogr., 37, 506-519, https://doi.org/10.1111/J.1365-2699.2009.02203.X, 2010.

Voarintsoa, N. R. G., Brook, G. A., Liang, F. Y., Marais, E., Hardt, B., Cheng, H., Edwards, R. L., and Railsback, L. B.: Stalagmite multi-proxy evidence of wet and dry intervals in northeastern Namibia: Linkage to latitudinal shifts of the Inter-Tropical Convergence Zone and changing solar activity from AD 1400 to 1950, The Holocene, 27, 384-396, https://doi.org/10.1177/0959683616660170, 2017a.

Voarintsoa, N. R. G., Wang, L., Bruce Railsback, L., Brook, G. A., Liang, F., Cheng, H., and Lawrence Edwards, R.: Multiple proxy analyses of a $U$ / Th-dated stalagmite to reconstruct paleoenvironmental changes in northwestern Madagascar between $370 \mathrm{CE}$ and 1300 CE, Palaeogeogr. Palaeocl., 469, 138-155, $2017 \mathrm{~b}$.

Voarintsoa, N. R. G., Railsback, L. B., Brook, G. A., Wang, L., Kathayat, G., Cheng, H., Li, X., Edwards, R. L., Rakotondrazafy, A. F. M., and Madison Razanatseheno, M. O.: Three distinct Holocene intervals revealed in NW Madagascar: evidence from two stalagmites from two caves, and implications for ITCZ dynamics, Clim. Past Discuss., https://doi.org/10.5194/cp2016-137, 2017c (data available at: https://www.ncdc.noaa.gov/ paleo-search/study/22970, last access: 28 November 2017).

Walker, M. J. C., Berkelhammer, M., Bjorck, S., Cwynar, L. C., Fisher, D. A., Long, A. J., Lowe, J. J., Newnham, R. M., Rasmussen, S. O., and Weiss, H.: Formal subdivision of the Holocene Series/Epoch: a Discussion Paper by a Working Group of INTIMATE (Integration of ice-core, marine and terrestrial records) and the Subcommission on Quaternary Stratigraphy (International Commission on Stratigraphy), J. Quaternary Sci., 27, 649-659, https://doi.org/10.1002/jqs.2565, 2012.

Wang, L.: Late Quaternary paleoenvironmental changes in Southern Africa and Madagascar: evidence from aeolian, fluvial, and cave deposits, Unpub dissertation, University of Georgia, Athens, Georgia, 312 pp., 2016.

Wang, L. and Brook, G. A.: Holocene Climate Changes in Northwest Madagascar: Evidence From a Two-meter-long Stalagmite From the Anjohibe Cave, Meeting Program of the Association of American Geographers, Published Online. Session 1512: Paleorecords of our Changing Earth I: Climate History and HumanEnvironment Interaction in the Old and New World Tropics, 2013.

Wang, X., Auler, A. S., Edwards, R. L., Cheng, H., Ito, E., Wang, Y., Kong, X., and Solheid, M.: Millennial-scale precipitation changes in southern Brazil over the past 90,000 years, Geophys. Res. Lett., 34, L23701, https://doi.org/10.1029/2007GL031149, 2007.

Wang, Y. J., Cheng, H., Edwards, R. L., He, Y. Q., Kong, X. G., An, Z. S., Wu, J. Y., Kelly, M. J., Dykoski, C. A., and $\mathrm{Li}, \mathrm{X}$. D.: The Holocene Asian monsoon: Links to solar changes and North Atlantic climate, Science, 308, 854-857, https://doi.org/10.1126/science.1106296, 2005.

Wanner, H. and Ritz, S. P.: A web-based Holocene Climate Atlas (HOCLAT): http://www.oeschger.unibe.ch/research/projects_ and_databases/web_based_holocene_climate_atlas_hoclat/ index_eng.html (last access: 29 November 2017), 2011.

Wanner, H., Beer, J., Butikofer, J., Crowley, T. J., Cubasch, U., Fluckiger, J., Goosse, H., Grosjean, M., Joos, F., Kaplan, J. O., 
Kuttel, M., Muller, S. A., Prentice, I. C., Solomina, O., Stocker, T. F., Tarasov, P., Wagner, M., and Widmann, M.: Mid- to Late Holocene climate change: an overview, Quaternary Sci. Rev., 27, 1791-1828, https://doi.org/10.1016/j.quascirev.2008.06.013, 2008.

Wanner, H., Solomina, O., Grosjean, M., Ritz, S. P., and Jetel, M.: Structure and origin of Holocene cold events, Quaternary Sci. Rev., 30, 3109-3123, https://doi.org/10.1016/j.quascirev.2011.07.010, 2011.

Wanner, H., Mercolli, L., Grosjean, M., and Ritz, S. P.: Holocene climate variability and change; a data-based review, J. Geol. Soc. London, 172, 254-263, https://doi.org/10.1144/jgs2013$101,2015$.

Weldeab, S., Lea, D. W., Schneider, R. R., and Andersen, N.: 155,000 years of West African Monsoon and ocean thermal evolution, Science, 316, 1303-1307, 2007.

Wiersma, A. P. and Renssen, H.: Model-data comparison for the $8.2 \mathrm{kaBP}$ event: confirmation of a forcing mechanism by catastrophic drainage of Laurentide Lakes, Quaternary Sci. Rev., 25, 63-88, https://doi.org/10.1016/j.quascirev.2005.07.009, 2006.

Wiersma, A. P., Roche, D. M., and Renssen, H.: Fingerprinting the $8.2 \mathrm{ka}$ event climate response in a coupled climate model, J. Quaternary Sci., 26, 118-127, https://doi.org/10.1002/jqs.1439, 2011.

Williamson, D., Jelinowska, A., Kissel, C., Tucholka, P., Gibert, E., Gasse, F., Massault, M., Taieb, M., Van Campo, E., and Wieckowski, K.: Mineral-magnetic proxies of erosion/oxidation cycles in tropical maar-lake sediments (Lake Tritrivakely, Madagascar): paleoenvironmental implications, Earth Planet. Sc. Lett., 155, 205-219, https://doi.org/10.1016/S0012-821x(97)00217-3, 1998.
Zhang, H.-L., Yu, K.-F., Zhao, J.-X., Feng, Y.-X., Lin, Y.-S., Zhou, W., and Liu, G.-H.: East Asian Summer Monsoon variations in the past $12.5 \mathrm{ka}$ : High-resolution $\delta^{18} \mathrm{O}$ record from a precisely dated aragonite stalagmite in central China, J. Asian Earth Sci., 73, 162-175, 2013.

Zhang, H., Cai, Y., Tan, L., Qin, S., and An, Z.: Stable isotope composition alteration produced by the aragonite-to-calcite transformation in speleothems and implications for paleoclimate reconstructions, Sediment Geol., 309, 1-14, 2014.

Zhang, R. and Delworth, T. L.: Simulated tropical response to a substantial weakening of the Atlantic thermohaline circulation, J. Climate, 18, 1853-1860, https://doi.org/10.1175/Jcli3460.1, 2005.

Zinke, J., Dullo, W. C., Heiss, G. A., and Eisenhauer, A.: ENSO and Indian Ocean subtropical dipole variability is recorded in a coral record off southwest Madagascar for the period 1659 to 1995, Earth Planet Sc. Lett., 228, 177-194, https://doi.org/10.1016/j.epsl.2004.09.028, 2004.

Zinke, T., Loveday, B. R., Reason, C. J. C., Dullo, W. C., and Kroon, D.: Madagascar corals track sea surface temperature variability in the Agulhas Current core region over the past 334 years, Sci. Rep., 4, 4393, https://doi.org/10.1038/srep04393, 2014. 